\title{
Microwave-assisted multicomponent synthesis of julolidines using silica-supported calix[4]arene as heterogeneous catalyst
}

\author{
Walysson Ferreira de Paiva a, Ingredy Bastos Braga a , João Vitor de Assis a, \\ Sandra Milena Bonilla Castañeda a, Angel Gabriel Sathicq ${ }^{\text {b }}$, Valeria Palermo ${ }^{\text {b }}$, \\ Gustavo Pablo Romanelli ${ }^{b}$, Ricardo Natalino ${ }^{a}$, Marcio José da Silva a, \\ Felipe Terra Martins ${ }^{c}$, Gustavo Senra Gonçalves de Carvalho ${ }^{d}$, \\ Giovanni Wilson Amarante ${ }^{\mathrm{d}}$, Sergio Antonio Fernandes ${ }^{\mathrm{a} \text {, * }}$ \\ a Grupo de Química Supramolecular e Biomimética (GQSB), Departamento de Química, CCE, Universidade Federal de Viçosa, Viçosa, MG, 36570-900, Brazil \\ b Centro de Investigación y Desarrollo en Ciencias Aplicadas "Dr. Jorge J. Ronco" (CINDECA-CCT-CONICET), Universidad Nacional de La Plata, Calle 47, No \\ 257, B1900AJK La Plata, Argentina \\ ' Instituto de Química, Universidade Federal de Goiás, Campus Samambaia, Goiânia, GO, CP 131, 74001-970, Brazil \\ d Departamento de Química, Universidade Federal de Juiz de Fora, Juiz de Fora, MG, 36036-900, Brazil
}

\section{A R T I C L E I N F O}

\section{Article history:}

Received 24 April 2019

Received in revised form

21 May 2019

Accepted 22 May 2019

Available online 29 May 2019

Keywords:

Calixarenes

Heterogeneous catalysis

Julolidines

Microwave-assisted

Multicomponent reactions

\begin{abstract}
A B S T R A C T
The application of immobilizing calixarene onto the surface of silica using a sol-gel method, as an efficient heterogeneous catalyst $\left(\mathrm{CX}_{4} \mathrm{SO}_{3} \mathrm{HSi}(n)\right)$ for multicomponent Povarov reaction has been described Catalytic activity of the $\mathrm{CX} 4 \mathrm{SO}_{3} \mathrm{HSi}(n)$ for the synthesis of julolidines under greener and environmentally benign conditions in simple and efficient method was explored. Notably, only $0.5 \mathrm{~mol} \%$ of the catalyst is sufficient to catalyze the Povarov solvent-free reaction under microwave-assistance. Besides, this protocol allows the construction of four new $\mathrm{C}-\mathrm{C}$ bonds and two $\mathrm{C}-\mathrm{N}$ bonds in a single step. To the best of our knowledge, this consists the first silica support calix[4]arene as a heterogeneous catalyst for multicomponent synthesis of julolidines.
\end{abstract}

() 2019 Elsevier Ltd. All rights reserved.

\section{Introduction}

High-efficiency catalysis is an inevitable topic of discussion in our society given our heavy reliance on it. The for development and advances in technology in order to meet the demands of a growing population for a sustainable synthetic chemistry [1]. Although homogeneous acid catalysis has attracted greater attention, their applications in industrial processes are hindered by the high cost, recovery catalyst, corrosion, toxicity and environmental safety. Recently, the combination of the chemical properties of acid organocatalysts and different solid supports such as carbon, polymers, silica and other metal oxides have received significant attention [2].

In the last years, research interest in calix[ $n$ ]arene chemistry has

\footnotetext{
* Corresponding author.

E-mail addresses: sefernandes@gmail.com, santonio@ufv.br (S.A. Fernandes).
}

increased dramatically due to their applications in several fields of chemistry, such as gels and films with fluorescent properties [3], molecular recognition [4], self-assembling systems [5], mechanically interlocked molecules [6], and nanoporous materials [7]. The application of calix $n$ ] arenes as organocatalysts in organic synthesis has become very popular [8]. On the other hand, the application of calix[ $n$ ]arenes as a heterogeneous catalyst for the chemical transformations remains largely unexplored [2e].: [9].

Julolidine and their derivatives are one of the most versatile and important classes of $\mathrm{N}$-heterocyclic and have attracted enormous attention from the scientific community for the potential in many applications such as for metal sensing [10], dye-sensitized solar cells [11], antiviral activity [12], antidepressants [13], tranquilizers [14], fluorescent probe [15], and nonlinear optical materials [16] (Fig. 1).

The traditional strategies for syntheses of julolidines usually involve a reaction of an aniline or tetrahydroquinoline with 1bromo-3-chloropropane [17] (Scheme 1). Traditional method has 


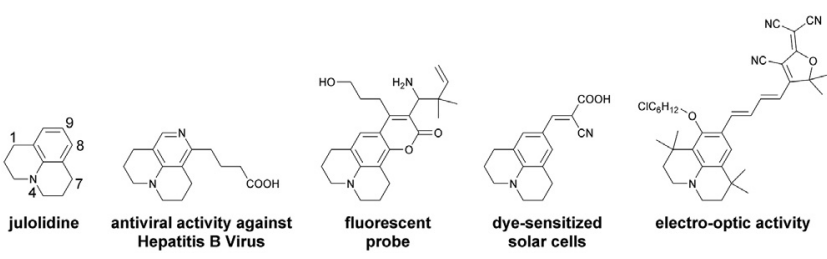

Fig. 1. Some examples and application of julolidine derivatives. purification processes, and hence minimize waste generation, rendering the green and sustainable transformations in synthetic chemistry [19]. The modularity of this approach is extremely suitable for the synthesis of functional materials, and it is, therefore, widely used for the fast generation of molecules for high-tech applications [20]. The multicomponent Povarov reaction (MCPR) of an in situ generated imine and an electron-rich dienophile under acid catalysis conditions is a versatile and widely used synthetic tech-<smiles>ClCCCBr</smiles>

Glass and Weissberger, 1946<smiles>Cc1ccc(N)cc1</smiles>

Mellhor and Merriman, 1995<smiles>Cc1cc2c3c(c1)N(C[C@H]1CCCO[C@@H]1CN(C)C)C[C@@H]3O[C@@H]1CCCO[C@H]21</smiles><smiles>[R]c1ccc(N)cc1</smiles>
GSY catalyst (Gold-polymer nanostructure-immobilized scandium) Kobayashi and Miyamura, 2013<smiles>[R]c1cc2c3c(c1)[C@@H]1OCC[C@@H]1CN3C[C@H]1CCO[C@H]21</smiles>

$\mathrm{Cl}=44 \%$ $\mathrm{H}=16 \%$ $\mathrm{CH}_{3} \mathrm{O}=14 \%$ $\mathrm{CH}_{3}=25 \%$
$\mathrm{MW}, 150^{\circ} \mathrm{C}, \mathrm{CX} 4 \mathrm{SO}_{3} \mathrm{H}(1 \mathrm{~mol} \%)$ $\mathrm{CH}_{3} \mathrm{CN}, 20$ min<smiles>[R]c1cc2c3c(c1)[C@@H]1OCC[C@H]1CN3C[C@H]1CCO[C@H]21</smiles>

$\mathrm{Cl}=54 \%$

$\mathrm{H}=22 \%$

$\mathrm{CH}_{3} \mathrm{O}=24 \%$

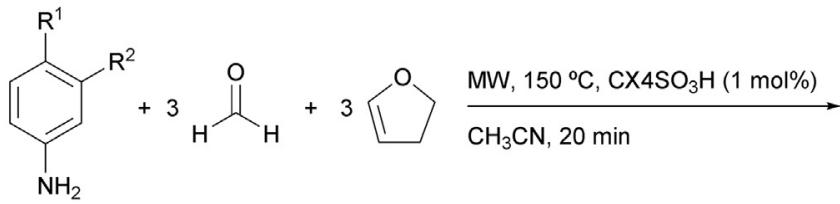

Abranches et al., 2018<smiles>[R]c1cc2c3c(c1[R])C1OCC[C@@H]1CN3C[C@H]1CCO[C@@H]21</smiles>

$19-47 \%$<smiles>[R]c1cc2c3c(c1[R])[C@@H]1OCC[C@@H]1CN3C[C@@H]1CCO[C@@H]21</smiles>

$23-49 \%$

34 julolidine derivatives

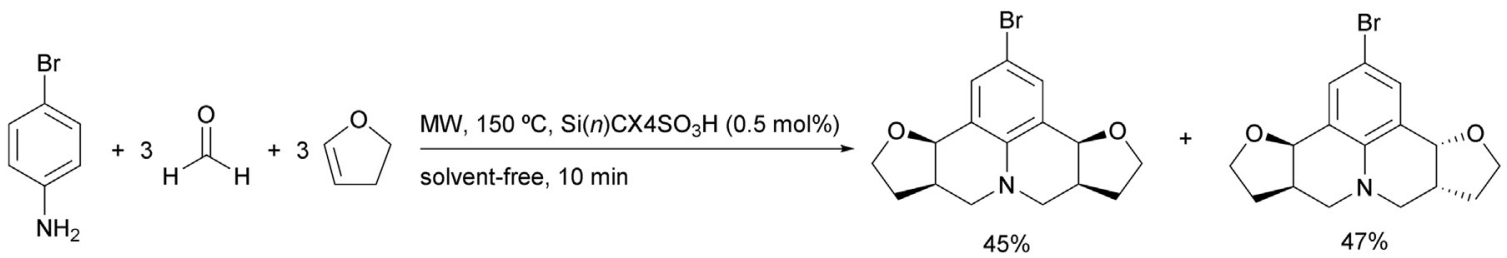

This work, transition-metal-free, solvent-free, Povarov Reactions (MCPRs)

Scheme 1. Different Variation on the Pathways for the Synthesis of Julolidines.

the disadvantage of offering few alternatives for introducing substituents into the julolidine skeleton, in C-8 or C -9 and especially in the alkyl moiety [18].

Multicomponent reactions (MCRs), defined as one-pot reactions, constitute an important group of transformations that combine many aspects of an ideal synthesis, such as operational simplicity, atom economy, bond forming efficiency, facile automation, reduction in the number of workup, extraction and nique adding aspects of sustainability for the construction of tetrahydroquinolines [8a,21], and quinolines [22].

The MCPR appears as a green alternative for the synthesis of julolidines derivatives and remains largely unexplored [23] (Scheme 1). Herein, a simple, effective and eco-friendly approach to the MCPR of julolidines derivatives using silica supported $p$-sulfonic acid calix[4]arene $\left(\mathrm{CX}_{4} \mathrm{SO}_{3} \mathrm{HSi}(n)\right)$ as a recoverable and reusable heterogeneous catalyst under solvent-free conditions is 
presented.

\section{Results and discussion}

\subsection{Catalysis synthesis $\mathrm{CX}_{4} \mathrm{SO}_{3} \mathrm{HSi}(\mathrm{n})$}

Catalysts was synthesized using a sol-gel technique. A mixture of $\mathrm{CX} 4 \mathrm{SO}_{3} \mathrm{H}$, water and a hydrochloric acid solution was added to tetraethyl orthosilicate. The mixture was stirred for $5 \mathrm{~h}$ at room temperature. Then, the mixture was allowed to stand for 3 days, and after breaking the formed hydrogel with a Teflon stick, the sample was dried in a vacuum for one week at room temperature (Scheme 2) [2e].

\subsection{Acid-based property}

The ion exchange capacities of $\mathrm{CX}_{4} \mathrm{SO}_{3} \mathrm{HSi}(n)$ were determined by acid-base titration and potentiometric titration. The acid capacity of the sample $\mathrm{CX}_{4} \mathrm{SO}_{3} \mathrm{HSi}(n)$ catalyst was determined by titration with $5 \times 10^{-3} \mathrm{M} \mathrm{NaOH}_{(\mathrm{aq})}$ [24], being found a value of $0.32 \mathrm{mmol} \mathrm{H}^{+} / \mathrm{g}$ of catalyst. The strength of the acid sites, obtained by potentiometric titration with $n$-butylamine, can be classified according to the following scale: $\mathrm{E}>100 \mathrm{mV}$ (very strong sites); $0<\mathrm{E}<100 \mathrm{mV}$ (strong sites); $-100<\mathrm{E}<0 \mathrm{mV}$ (weak sites) and $\mathrm{E}<-100 \mathrm{mV}$ (very weak sites) [25]. The acid strength for $\mathrm{CX}_{4} \mathrm{SO}_{3} \mathrm{HSi}(n)$ catalyst was $205 \mathrm{mV}$, indicating the presence of very strong sites.

\subsection{X-ray diffraction}

The XRD pattern peaks were obtained between $5^{\circ}$ and $50^{\circ}$. Even though no X-ray diffraction peaks were detected in the XRD pattern of the supported samples, the presence of some ordering cannot be ruled out because they may be less than $40 \AA$ in size, which is beyond the detection limit of the XRD technique. The broad X-ray diffraction patterns may indicate long-range disordered nature. ${ }^{2 \mathrm{e}}$

\subsection{Elemental analysis determination}

The elemental analysis of the included $\mathrm{CX} 4 \mathrm{SO}_{3} \mathrm{H}$ show a carbon content of $5.92 \%$, corresponding with a $\% \mathrm{w} / \mathrm{w}$ of active phase of the $\mathrm{CX}_{4} \mathrm{SO}_{3} \mathrm{HSi}(n)$ catalyst in the silica matrix of $15.1 \%$.

\subsection{FT-IR analysis}

Fig. 2 shows the FTIR spectra of activated mesoporous silica, $\mathrm{CX}_{4} \mathrm{SO}_{3} \mathrm{H}$ and $\mathrm{CX} 4 \mathrm{SO}_{3} \mathrm{HSi}(n)$. The FTIR spectrum of unmodified mesoporous silica is relatively simple and well assigned [26]. The strong absorption band at $1068 \mathrm{~cm}^{-1}$ is attributed to the $\mathrm{Si}-\mathrm{O}-\mathrm{Si}$ bending of silica, while the absorbance at 1629 and $3298 \mathrm{~cm}^{-1}$ is assigned to the surface hydroxyl groups of mesoporous silica (Fig. 2).

A typical spectrum of $\mathrm{CX} 4 \mathrm{SO}_{3} \mathrm{H}$ (Fig. 2) presents four main bands at $3134,1449,1030$ and $783 \mathrm{~cm}^{-1}$ which are assigned to the $\mathrm{OH}$ bond of the phenol group, the weak absorption peak of due to the methylene $\mathrm{CH}$ bending, the strong absorption peak of $\mathrm{S}-\mathrm{O}$ bond

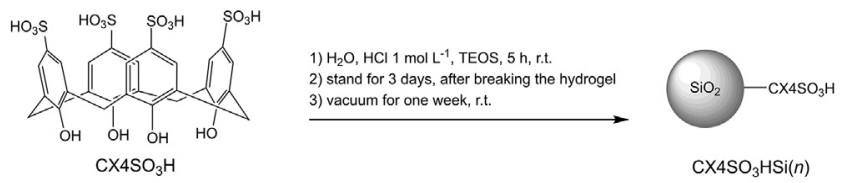

Scheme 2. Synthesis of the catalyst $\mathrm{CX}_{4} \mathrm{SO}_{3} \mathrm{HSi}(n)$.

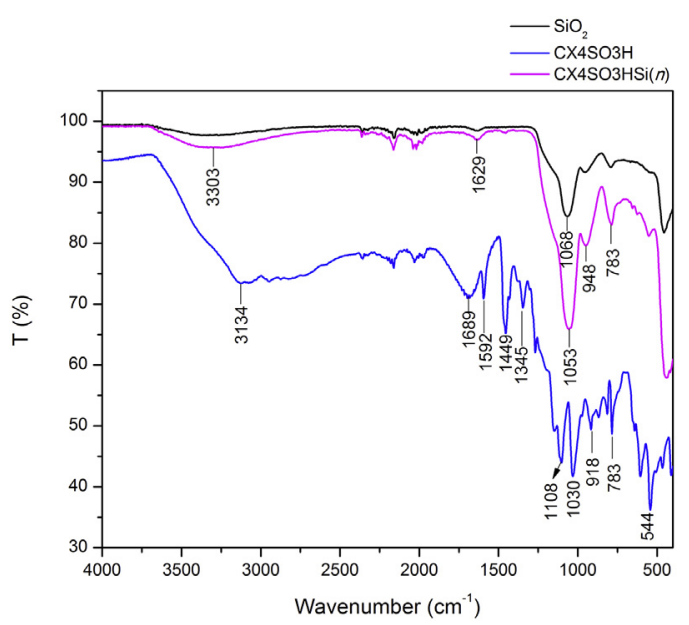

Fig. 2. FTIR spectra of $(-) \mathrm{SiO}_{2},(-) \mathrm{CX}_{4} \mathrm{SO}_{3} \mathrm{H}$ and $(-) \mathrm{CX}_{4} \mathrm{SO}_{3} \mathrm{HSi}(n)$.

and the $\mathrm{CX}_{4} \mathrm{SO}_{3} \mathrm{H}$ aromatic hydrogen angular deformations, respectively [27]. The spectrum of $\mathrm{CX}_{4} \mathrm{SO}_{3} \mathrm{HSi}(n)$ (Fig. 2) presents four main bands at 3303, 1449, 1053 and $783 \mathrm{~cm}^{-1}$ assigned to the stretching hydroxyl group stretching from both mesoporous silica and the $\mathrm{CX} 4 \mathrm{SO}_{3} \mathrm{H}$ molecule, the weak absorption peak of methylene bridges, the strong absorption peak of $\mathrm{S}-\mathrm{O}$ which broadened the angular deformation band the peak of $\mathrm{Si}-\mathrm{O}-\mathrm{Si}$ and $\mathrm{CX}_{4} \mathrm{SO}_{3} \mathrm{H}$ aromatic hydrogens, respectively [28].

\section{6. ${ }^{13} \mathrm{C}$ and ${ }^{29}$ Si MAS-NMR}

${ }^{13} \mathrm{C}$ MAS-NMR of pure $\mathrm{CX}_{4} \mathrm{SO}_{3} \mathrm{H}$ (Fig. 3a) present the following peaks: 30.1 (-CH2-); $127.9(\mathrm{Ar}) ; 137.0(\mathrm{Ar}) ; 150.6(\mathrm{Ar})$. These signals are also present in the $\mathrm{CX}_{4} \mathrm{SO}_{3} \mathrm{HSi}(n)$ (Fig. $3 \mathrm{~b}$ ), which proves that the $\mathrm{CX} 4 \mathrm{SO}_{3} \mathrm{H}$ structure is maintained after the inclusion. Remaining ethoxy groups of the tetraethyl orthosilicate give peaks at 9.8 and $71.2 \mathrm{ppm}$; these peaks possess a small linewidth due to the high mobility of the ethoxy groups [29].

${ }^{29} \mathrm{Si}$ MAS-NMR of $\mathrm{CX} 4 \mathrm{SO}_{3} \mathrm{HSi}(n)$ catalyst are shown in Fig. 3d. Three overlapping signals are present at -111.2 (53.7); -101.7 (38.4); -91.8 (7.9) which can be assigned to Q4, Q3 and Q2, respectively $[29,30]$. The same group of signals can be seen in pure silica (Fig. 3c) showing that the support structure is maintained after the $\mathrm{CX}_{4} \mathrm{SO}_{3} \mathrm{H}$ inclusion. The average distribution of $\mathrm{Q} 4, \mathrm{Q}$,

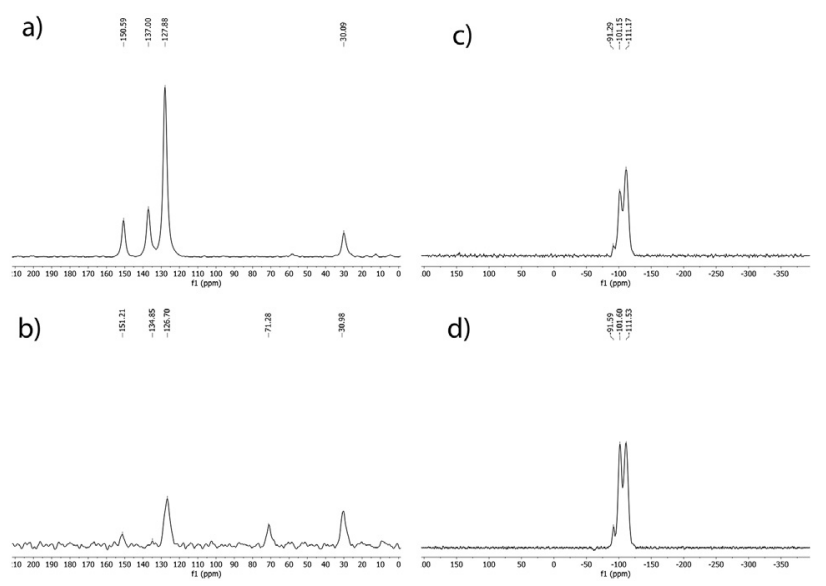

Fig. 3. Solid-state NMR spectra: a) ${ }^{13} \mathrm{C}$ NMR of $\mathrm{CX}_{4} \mathrm{SO}_{3} \mathrm{H}$; b) ${ }^{13} \mathrm{C}$ NMR of $\mathrm{CX}_{4} \mathrm{SO}_{3} \mathrm{HSi}(n)$; c) ${ }^{29} \mathrm{Si}$ NMR of support; d) ${ }^{29} \mathrm{Si} \mathrm{NMR} \mathrm{of} \mathrm{CX} 4 \mathrm{SO}_{3} \mathrm{HSi}(n)$. 
and Q2 are according to literature [29]. The amount of geminal silanols (Q2) has a small increase when the $\mathrm{CX}_{4} \mathrm{SO}_{3} \mathrm{H}$ is present.

\subsection{Textural properties}

The porosity of a) silica, b) $\mathrm{CX}_{4} \mathrm{SO}_{3} \mathrm{H}$ and c) $\mathrm{CX}_{4} \mathrm{SO}_{3} \mathrm{HSi}(n)$ was measured using nitrogen physisorption and the adsorptiondesorption isotherms are compared in Fig. 4. The Barrett-JoynerHalenda (BJH) pore size distribution (i.e., insert on Fig. 4) shows that the silica has a higher range of pore diameter (ca. $0.4-1.6 \mathrm{~nm}$ ) with maximum at ca. $0.5 \mathrm{~nm}$ (Fig. 4a), while $\mathrm{CX}_{4} \mathrm{SO}_{3} \mathrm{H}$ has range of pore diameters (ca. $0.9-1.35 \mathrm{~nm}$ ), with a well-defined maximum at $1.1 \mathrm{~nm}$ (Fig. 4b). Conversely, the $\mathrm{CX}_{4} \mathrm{SO}_{3} \mathrm{HSi}(n)$ presented an intermediate range of pore diameter (ca. $0.4-1.25 \mathrm{~nm}$ ), with a maximum of $0.8 \mathrm{~nm}$. The bimodal $\mathrm{BJH}$ pore size distribution was observed for $\mathrm{CX}_{4} \mathrm{SO}_{3} \mathrm{HSi}(n)$, whereas the unimodal mesoporous distribution of silica before immobilization is an evidence of this material of its microporosity. This behavior was previously noticed by Katz et al., which immobilized calixarenes derivatives onto surface of silica [31].

On the other hand, the adsorption-desorption isotherms obtained from silica and $\mathrm{CX}_{4} \mathrm{SO}_{3} \mathrm{H}$ (Fig. $4 \mathrm{a}$ and b) were substantially different form that obtained from silica-supported $\mathrm{CX}_{4} \mathrm{SO}_{3} \mathrm{HSi}(n)$ (Fig. 4c). Typically, the BET isotherms obtained from silica were of type I, typical of microporous solids. The isotherms of calix[4]arene were type III, typical of solids with low porosity (i.e., nonporous or microporous materials) [32]. Conversely, the silica-supported calix [4]arene presented isotherms typical of mesoporous solids (Type V) [33]. Indeed, the hysteresis observed in the isotherms of Fig. 5c was generated by differences in the processes of adsorption/desorption. This behavior may be assigned to the capillary condensation phenomena, triggered by inclusion of calix[4] arene (a solid with lower porosity) into silica (i.e. a microporous solid). The supporting of calix[4]arene on the silica surface generated a mesoporous solid, where the adsorption on mesoporous solids proceeds via multilayer adsorption followed by capillary condensation, resulting in a Type $\mathrm{V}$ isotherm.

Table 1 shows the surface area and porous volume of the support, $\mathrm{CX} 4 \mathrm{SO}_{3} \mathrm{H}$ and $\mathrm{CX}_{4} \mathrm{SO}_{3} \mathrm{HSi}(n)$ catalyst, respectively. The inclusion of $\mathrm{CX} 4 \mathrm{SO}_{3} \mathrm{H}$ in the silica matrix generates a material with an area 10 times larger than the bulk $\mathrm{CX}_{4} \mathrm{SO}_{3} \mathrm{H}$ (Table 1).
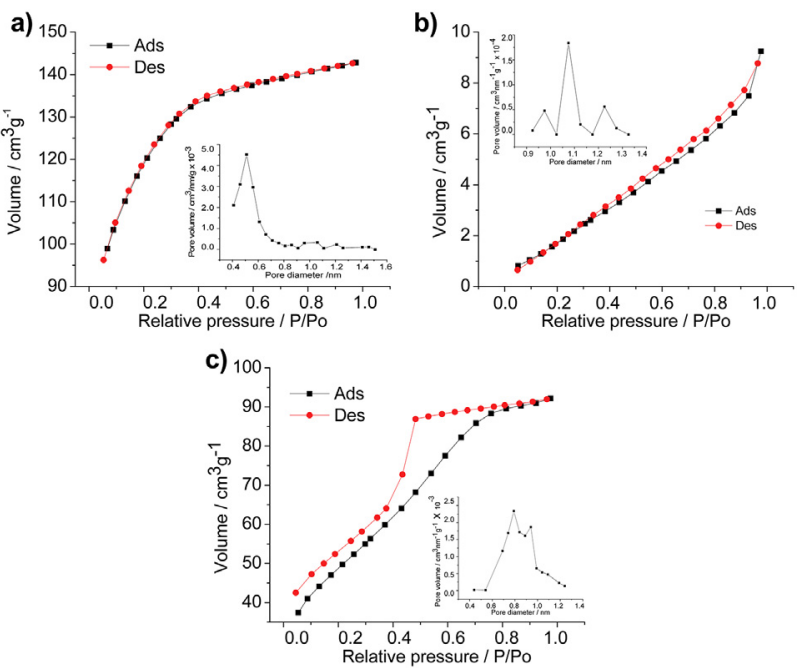

Fig. 4. a) $\mathrm{BJH}$ method of pore size distribution for silica, b) $\mathrm{CX}_{4} \mathrm{SO}_{3} \mathrm{H}$ and c) $\mathrm{CX} 4 \mathrm{SO}_{3} \mathrm{HSi}(n)$.

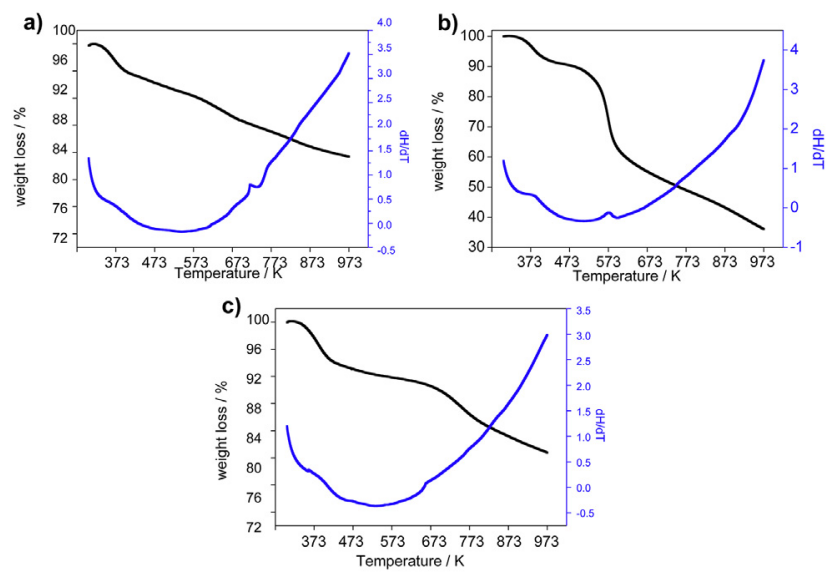

Fig. 5. High-resolution thermogravimetric analysis (TG) of a) silica, b) $\mathrm{CX}_{4} \mathrm{SO}_{3} \mathrm{H}$ and c) $\mathrm{CX}_{4} \mathrm{SO}_{3} \mathrm{HSi}(n)$

Table 1

Surface and porosity parameters of Silica, $\mathrm{CX}_{4} \mathrm{SO}_{3} \mathrm{H}$ and $\mathrm{CX} 4 \mathrm{SO}_{3} \mathrm{HSi}(n)$.

\begin{tabular}{llll}
\hline Entry & Catalyst & Surface area $\left(\mathrm{m}^{2} \mathrm{~g}^{-1}\right)$ & Pore volume $\left(\mathrm{m}^{3} \mathrm{~g}^{-1}\right)$ \\
\hline 1 & Silica & 52.729 & 0.199 \\
2 & $\mathrm{CX}_{4} \mathrm{SO}_{3} \mathrm{H}$ & 2.842 & 0.013 \\
3 & $\mathrm{CX}_{4} \mathrm{SO}_{3} \mathrm{HSi}(n)$ & 33.958 & 0.131 \\
\hline
\end{tabular}

\subsection{Thermogravimetric analysis (TGA)}

The thermal stability of the organosilicas was examined by thermogravimetric analysis (TGA). TG curves of (a) silica, (b) $\mathrm{CX}_{4} \mathrm{SO}_{3} \mathrm{H}$ and (c) $\mathrm{CX}_{4} \mathrm{SO}_{3} \mathrm{HSi}(n)$ were determined (Fig. 5). TG curves showed that silica and $\mathrm{CX}_{4} \mathrm{SO}_{3} \mathrm{HSi}(n)$ exhibited a lower mass loss than $\mathrm{CX}_{4} \mathrm{SO}_{3} \mathrm{H}$ (ca. $16 \%$ for (a) and (c), and $65 \%$ for (b), respectively. The stage of mass loss started below $100{ }^{\circ} \mathrm{C}$ due to loss of the adsorbed water. Differently than TG curve of silica that presented only a well-defined stage of mass loss (Fig. 5a), $\mathrm{CX} 4 \mathrm{SO}_{3} \mathrm{H}$ (Fig. 5b) and $\mathrm{CX}_{4} \mathrm{SO}_{3} \mathrm{HSi}(n)$ (Fig. $5 \mathrm{c}$ ) had two steps where the decrease of mass was well noticed. The second decrease of mass observed in the last two TG curves should be of (b) and (c) should be attributed to the decomposition of $\mathrm{CX}_{4} \mathrm{SO}_{3} \mathrm{H}$ [34]. This change in the TG curve of $\mathrm{CX}_{4} \mathrm{SO}_{3} \mathrm{HSi}(n)$ relative to that of pure silica demonstrates that silica was successfully modified with $\mathrm{CX} 4 \mathrm{SO}_{3} \mathrm{H}$. Furthermore, the profile of curves shown in Fig. 5 agree with literature data [35]. The endothermic peak on DSC curve of $\mathrm{CX} 4 \mathrm{SO}_{3} \mathrm{H}$ may be assigned to the decomposition of sulfonic groups of $\mathrm{CX}_{4} \mathrm{SO}_{3} \mathrm{H}$, which was less pronounced in the DSC curve of $\mathrm{CX}_{4} \mathrm{SO}_{3} \mathrm{HSi}(n)$.

\subsection{Application of $\mathrm{CX}_{4} \mathrm{SO}_{3} \mathrm{HSi}(\mathrm{n})$ in the synthesis of julolidines}

The excellent results for synthesis of julolidines employing $\mathrm{CX} 4 \mathrm{SO}_{3} \mathrm{H}$ [23a], mentioned above, inspired us to use $\mathrm{CX}_{4} \mathrm{SO}_{3} \mathrm{HSi}(n)$ as a heterogeneous catalyst to obtain julolidines. The heterogeneous $\mathrm{CX}_{4} \mathrm{SO}_{3} \mathrm{HSi}(n)$ catalyst, previously prepared, was employed in all reactions. In order to determine the best reaction condition, 4bromoaniline (1a), formaldehyde (2) and 2,3-dihydrofuran (3) were used as substrates and the reactions were carried out in the presence of $\mathrm{CX}_{4} \mathrm{SO}_{3} \mathrm{HSi}(n)$ as catalyst $(0.5 \mathrm{~mol} \%)$ under microwave irradiation. A series of solvents as well as solvent-free conditions (Table 2, entry 1-6) were tested to determine the best condition for obtaining julolidines in very good yields. The use of water [8a], methanol or ethanol as protic solvents yielded the julolidine 1 $[( \pm)-\mathrm{T}+\mathrm{C}]$ in $14 \%, 79 \%$ and $53 \%$, respectively (Table 2 , entries $1-3$ ). 
Table 2

Effect of the solvents, catalyst loading, power and reaction time on the formation of julolidines ${ }^{\mathrm{a}} .4$

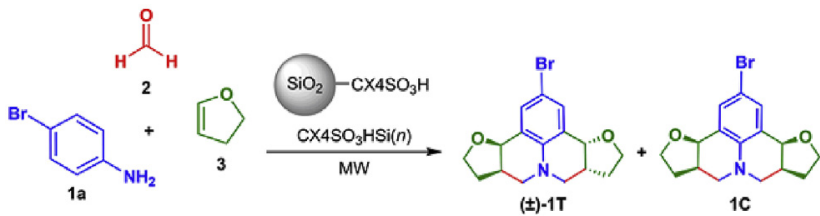

\begin{tabular}{|c|c|c|c|c|c|}
\hline Entry & Solvent & Power (W) & Catalyst loading ( $\mathrm{mol} \%)$ & Time (min) & Total yield $^{\mathrm{b}}(\%)$ \\
\hline 1 & $\mathrm{H}_{2} \mathrm{O}$ & 100 & 0.5 & 10 & 14 \\
\hline 2 & $\mathrm{MeOH}$ & 100 & 0.5 & 10 & 79 \\
\hline 3 & EtOH & 100 & 0.5 & 10 & 53 \\
\hline 4 & $\mathrm{MeCN}$ & 100 & 0.5 & 10 & 84 \\
\hline 5 & - & 100 & 0.5 & 10 & 87 \\
\hline 6 & - & 100 & 1.0 & 10 & 57 \\
\hline 7 & - & 100 & 2.0 & 10 & 56 \\
\hline 8 & - & 200 & 0.5 & 10 & 85 \\
\hline 9 & - & 300 & 0.5 & 10 & 70 \\
\hline 10 & - & 50 & 0.5 & 10 & 92 \\
\hline 11 & - & 50 & 0.5 & 5 & 59 \\
\hline 12 & - & 50 & 0.5 & 15 & 24 \\
\hline 13 & - & 50 & 0.5 & 20 & 24 \\
\hline 14 & - & 50 & - & 10 & 25 \\
\hline 15 & - & 50 & support & 10 & 9 \\
\hline
\end{tabular}

${ }^{a}$ Reaction conditions: 4-bromoaniline 1a $(0.5 \mathrm{mmol})$, formaldehyde $\mathbf{2}$ (1.5 mmol), 2,3-dihydrofuran $\mathbf{3}$ (1.5 mmol).

b Total yield $1[( \pm)-T+C]$ for the crude mixture of $( \pm)-1 T$ and $1 C$ was determined by GC/MS analysis.

The $1[( \pm)-T+C]$ was also obtained in good yield when aprotic solvents, such as acetonitrile or solvent-free were used (Table 2 , entries 4 and 5). Once determined that a solvent-free reaction was the best condition to obtain $1[( \pm)-\mathrm{T}+\mathrm{C}]$, we further investigated what the minimum amount of catalyst $\mathrm{CX}_{4} \mathrm{SO}_{3} \mathrm{HSi}(n)$ required to achieve the maximum reaction yield. The $1[( \pm)-\mathrm{T}+\mathrm{C}]$ yield decreased to $57 \%$ and $56 \%$ when the amount of $\mathrm{CX} 4 \mathrm{SO}_{3} \mathrm{HSi}(n)$ was increased from $0.5 \mathrm{~mol} \%$ to $1.0 \mathrm{~mol} \%$ and $2.0 \mathrm{~mol} \%$ (Table 2, entries $5-7)$. By using the microwave irradiation and different power (50, $100,200$ and $300 \mathrm{~W})$, the $1[( \pm)-\mathrm{T}+\mathrm{C}]$ yield decreased to $92 \%, 87 \%$, $85 \%$ and $70 \%$ when the power was increased from $50 \mathrm{~W}, 100 \mathrm{~W}$, $200 \mathrm{~W}$ and $300 \mathrm{~W}$ (Table 2, entries 5 and 8-10). The yield of 1 $[( \pm)-T+C]$ decreased to $59 \%$ when the reaction time was decreased to $5 \mathrm{~min}$ (Table 2, entry 11), and the yields also decrease for longer reaction times (Table 2, entries 12 and 13 ). The $1[( \pm)-T+C]$ yield in the catalyst-free reactions or in the presence of the support (TEOS) reactions was 25 and 9\%, respectively (Table 2, entries 14 and 15). Overall, the use of solvent-free, a reaction time of $10 \mathrm{~min}$, and $0.5 \mathrm{~mol} \%$ of $\mathrm{CX}_{4 \mathrm{SO}_{3}} \mathrm{HSi}(n)$ catalyst provided $1[( \pm)-\mathrm{T}+\mathrm{C}]$ in excellent yield (92\%).

The catalytic activity of $\mathrm{CX} 4 \mathrm{SO}_{3} \mathrm{HSi}(n)$ was compared to that of two commercials heterogeneous Brønsted acids, Amberlyst and $\mathrm{H}_{3} \mathrm{PW}_{12} \mathrm{O}_{40}$. Notably, the use of $\mathrm{CX}_{4} \mathrm{SO}_{3} \mathrm{HSi}(n)$ was considerably more efficient than the other catalysts tested for this reaction (Table 3, entries 1-3).

Given the optimized reaction conditions for the synthesis of 1

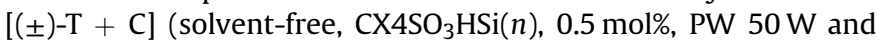
$10 \mathrm{~min}$ ), the generality of the MCPR was evaluated. For this purpose, aromatic anilines containing electron-donating and electronwithdrawing groups at para-position aromatic ring were evaluated (Scheme 3). The best yields were obtained for the $p$-halogensubstituted anilines ( $\mathrm{F}(97 \%), \mathrm{Cl}(94 \%), \mathrm{Br}(92 \%)$ and I (83\%)). These yields were very similar than those obtained by other methods for p-fluor, $p$-bromine and higher for anilines $\mathrm{Cl}, \mathrm{I}, \mathrm{H}$ and $\mathrm{CH}_{3}$ for $p$ substitudes [23a]. The substituents on the aniline ring had no noticeable effect on the diastereoisomeric excess (Scheme 3). In general, low stereoselectivity is observed in the reaction [23a,].
Table 3

Effect of different heterogeneous catalysts on the formation of julolidines. ${ }^{\mathrm{a}} 5$

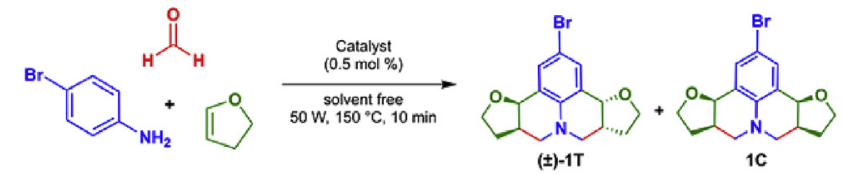

\begin{tabular}{lll}
\hline Entry & Catalyst & Yield $^{\mathrm{b}}(\%)$ \\
\hline 1 & $\mathrm{CX} 4 \mathrm{SO}_{3} \mathrm{HSi}(n)$ & 92 \\
2 & Amberlyst $^{\circledR}$ IRA-400 & 23 \\
3 & $\mathrm{H}_{3} \mathrm{PW}_{12} \mathrm{O}_{4}$ & 31 \\
\hline
\end{tabular}

a Reaction conditions: 4-bromoaniline $\mathbf{1 a}(0.5 \mathrm{mmol})$, formaldehyde $\mathbf{2}(1.5 \mathrm{mmol})$, 2,3-dihydrofuran 3 (1.5 mmol).

b Total yield $1[( \pm)-T+C]$ for the crude mixture of $( \pm)-1 T$ and $1 C$ was determined by GC/MS analysis.
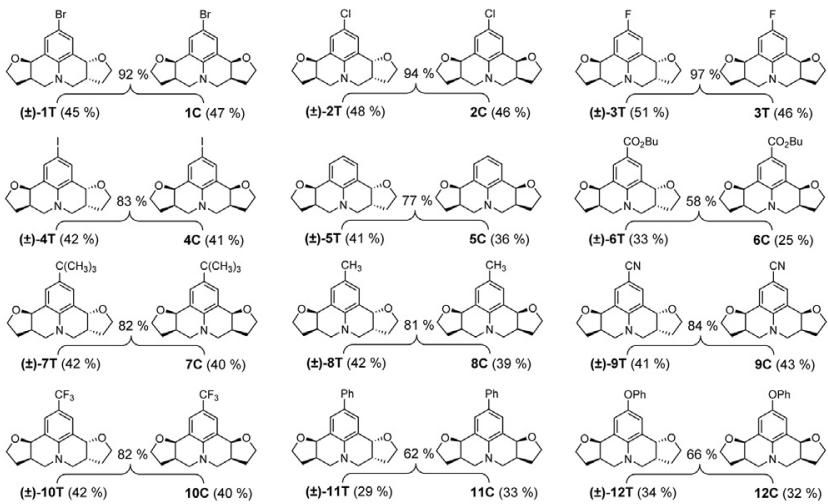

Scheme 3. Scope of the Reaction for Different Anilines. Reagents and conditions: aniline $(0.5 \mathrm{mmol})$, formaldehyde $(1.5 \mathrm{mmol})$, and 2,3-dihydrofuran $(1.5 \mathrm{mmol})$ in the MW $50 \mathrm{~W}, 10 \mathrm{~min}$, solvent-free. The yield of each julolidine is presented in parentheses. Isolated yield. 
[23b,23d,23e,36] The cis/trans isomerism of the synthesized compounds was determined by ${ }^{1} \mathrm{H}$ NMR based on the values of the coupling constants (Jcis and Jtrans) and the chemical shift values (compared to the previously reported results) [23a]. Despite the low selective ratio between diastereomers, the reactivity was impressive and both diastereomers could be characterized.

Suitably-shaped crystals of the ( \pm )-trans diastereomer could be isolated and allowed for its structure elucidation by the singlecrystal X-ray diffraction technique. As can be viewed in Fig. 6, its relative configuration was unambiguously determined from this experiment. All methine carbons have $S$-stereochemistry in the chosen asymmetric unit, which is shown in this picture, even though the enantiomeric counterpart with $R$-stereochemistry for these four carbons is also present in the crystal lattice due to the crystallization in a centrosymmetric space group (monoclinic $C 2 / c$ ).

\subsection{Catalyst recycling}

According to the principles of green chemistry that seek to sustainable synthetic chemistry, the recovery and reuse of the catalyst is quite important. The catalyst recycling experiment was conducted using the model reaction of 4-bromoaniline (1a), formaldehyde (2), 2,3-dihydrofuran (3), and $\mathrm{CX}_{4} \mathrm{SO}_{3} \mathrm{HSi}(n)$ catalyst in solvent-free under microwave irradiation, conditions optimized. These results are summarized in Fig. 7. After completion of the reaction, dichloromethane was added, and the catalyst recovered for upon filtration. After recovery, the catalyst was obtained as a solid residue in approximately $90 \%$ crude yield (Fig. 7 ). The catalyst a significant decrease in yields with consecutive catalytic cycles was observed, which can be attributed to deactivation of the catalyst.

\subsection{Reaction mechanism}

Based on the recently published work by Abranches et al. [23a] and on the interception and the interception of oxonium and dioxonium ion by methanol, the catalytic cycle for the formation of the julolidine is presented in Scheme 4 . The first step consists of the reaction between 4-bromoaniline and the activated formaldehyde to provide the iminium ion via a Mannich reaction (Scheme 4). The addition of 2,3-dihydrofuran to the iminium ion forms the corresponding oxonium ion (Scheme 4). Then, the formation of a second iminium ion occurs, which subsequently leads to the formation of the dioxonium ion (Scheme 4). That is followed by an intramolecular electrophilic aromatic substitution to furnish the tetrahydroquinoline oxonium ion, which undergoes a second electrophilic aromatic substitution reaction to form the final julolidine and regenerate the $\mathrm{CX}_{4} \mathrm{SO}_{3} \mathrm{HSi}(n)$ catalyst.

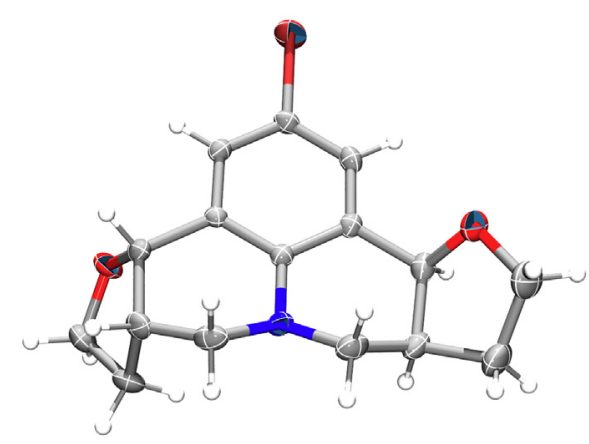

Fig. 6. View of the chosen asymmetric unit of the ( \pm )-trans diastereomer with nonhydrogen atoms represented by their corresponding $30 \%$ probability ellipsoids.

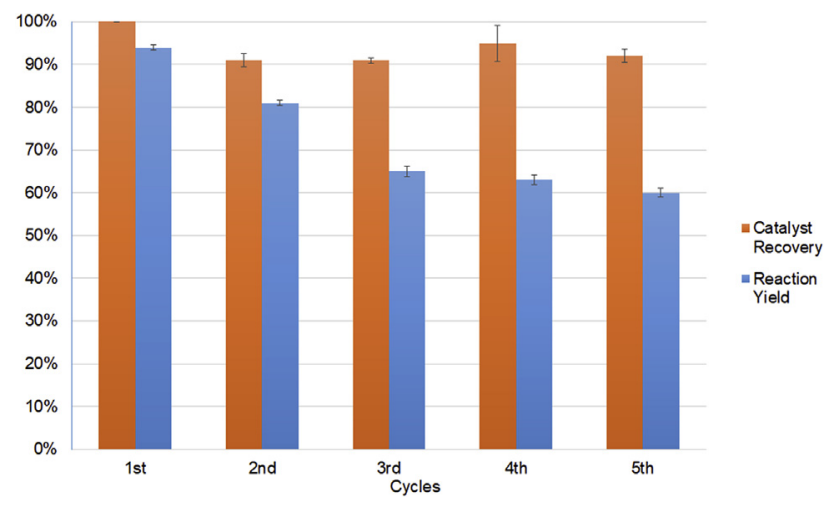

Fig. 7. Recovery and reuse of $\mathrm{CX}_{4} \mathrm{SO}_{3} \mathrm{HSi}(n)$ as the catalyst in the synthesis of 1 $[( \pm)-\mathrm{T}+\mathrm{C}]$. Yield determined by GC/MS.

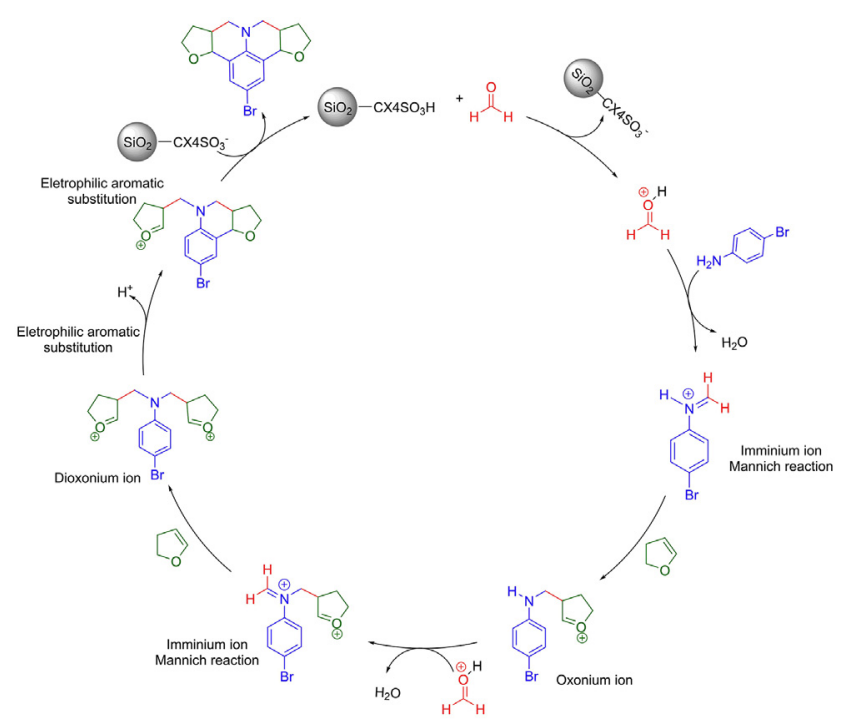

Scheme 4. Proposed Catalytic Cycle for the Synthesis of Julolidines.

\section{Conclusions}

In the present article, we have successfully functionalized the surface of mesoporous silica via sol-gel by $p$-sulfonic acid calix[4] arene heterogeneous catalyst $\mathrm{CX}_{4} \mathrm{SO}_{3} \mathrm{HSi}(n)$ and characterized by BET, FT-IR, TGA, ${ }^{13} \mathrm{C}$ and ${ }^{29} \mathrm{Si}$ NMR. The catalyst then applied in the multicomponent reaction of Povarov under solvent-free conditions with high catalytic activity in the synthesis of julolidines. Two main diastereomers, cis and ( \pm )-trans, were obtained and fully characterized. Moreover, the method allows the formation of four new $\mathrm{C}-\mathrm{C}$ and two $\mathrm{C}-\mathrm{N}$ bonds in a one-step stepwise transformation. Recyclability and reuse of the $\mathrm{CX}_{4} \mathrm{SO}_{3} \mathrm{HSi}(n)$ catalyst was established for up to five successive runs without no dramatic loss in the reaction profile. The relative configurations of the product 1( \pm -trans was determined by X-ray crystallographic experiments. This consists the first silica support calix[4]arene as a heterogeneous catalyst for multicomponent synthesis of julolidines.

\section{Experimental}

\subsection{General information}

Analytical grade commercial solvents and reagents included $p$ sulfonic acid calix[4] arene $\left(\mathrm{CX} 4 \mathrm{SO}_{3} \mathrm{H}\right)$ were purchased from Sigma 
Aldrich, Fluka, and Merck, and used as received. Column chromatography was carried out using $0.063-0.2 \mathrm{~mm}$ silica gel (DavisilR LC60A 40-63 $\mu \mathrm{m}$ ) with the indicated solvent. Thin layer chromatography (TLC) was carried out using $0.2 \mathrm{~mm}$ Kieselgel $\mathrm{F}_{254}$ (Merck) silica plates, and compounds were visualized using UV irradiation at $365 \mathrm{~nm}$.

Infrared spectra were recorded as neat using a FT-IR Varian 660 Fourier transform infrared spectrometer. Values are expressed in wavenumbers $\left(\mathrm{cm}^{-1}\right)$ and recorded in a range of $4000-400 \mathrm{~cm}^{-1}$.

NMR spectra were recorded at $25^{\circ} \mathrm{C}$ in $\mathrm{CDCl}_{3}$ on a Varian Mercury 300 spectrometer operating at $300 \mathrm{MHz}$ for ${ }^{1} \mathrm{H}$ and $75 \mathrm{MHz}$ for ${ }^{13} \mathrm{C}$, and on a Bruker Avance III HD 500 spectrometer operating at $500 \mathrm{MHz}$ for ${ }^{1} \mathrm{H}$ and $125 \mathrm{MHz}$ for ${ }^{13} \mathrm{C}$. Solid-state NMR spectra were performed a Bruker Avance III HD 300 spectrometer operating at $75 \mathrm{MHz}$ for ${ }^{13} \mathrm{C}$ and $60 \mathrm{MHz}$ for ${ }^{29} \mathrm{Si}$.

All chemical shifts are reported in parts per million (ppm) and were measured relative to the solvent in which the sample was analyzed $\left(\mathrm{CDCl}_{3} \delta=7.26\right.$ for ${ }^{1} \mathrm{H}$ NMR and $\delta=77.0$ for ${ }^{13} \mathrm{C}$ NMR). Coupling constants $(J)$ are reported in hertz $(\mathrm{Hz})$.

Mass spectrum and diastereoselectivity were determined by gas chromatography coupled to a mass spectrometer using a SHIMADZU GCMS-QP2010C Ultra mass spectrometer and the method with the following specifications: column RTx-5 MS, $30 \mathrm{~m}$, DI $0.25 \mathrm{~mm}$; carrier gas helium; injector temperature of $290^{\circ} \mathrm{C}$; oven temperature of $40^{\circ} \mathrm{C}(2 \mathrm{~min})$, ramped at $20^{\circ} \mathrm{C} \mathrm{min}^{-1}$ up to $300^{\circ} \mathrm{C}$ (held for $15 \mathrm{~min}$ ).

\section{2. $\mathrm{CX}_{4} \mathrm{SO}_{3} \mathrm{H}$ included in silica sol-gel framework synthesis}

The $\mathrm{CX} 4 \mathrm{SO}_{3} \mathrm{HSi}(n)$ catalyst was prepared following a procedure reported in the literature with some minor modification. ${ }^{2 \mathrm{e}} \mathrm{A}$ mixture of $\mathrm{CX}_{4} \mathrm{SO}_{3} \mathrm{H}(0.600 \mathrm{~g})$, water $(4.5 \mathrm{~mL})$ and $1 \mathrm{~mol} \mathrm{~L}^{-1}$ hydrochloric acid $(0.5 \mathrm{~mL})$ was added to tetraethyl orthosilicate $(12.50 \mathrm{~mL})$. The mixture was stirred for $5 \mathrm{~h}$ at room temperature. Then, the mixture was allowed to stand for 3 days, and after breaking the formed hydrogel with a Teflon stick, the sample was dried under vacuum for one week at room temperature. The powdered sample was washed with distilled water $(3 \times 10 \mathrm{~mL})$ and dried under vacuum.

\subsection{Catalytic characterization}

\subsubsection{Acidity determination in aqueous media}

The acid capacity was determined by titration with $5 \times 10^{-3} \mathrm{M}$ $\mathrm{NaOH}_{(\mathrm{aq})}$. In a typical experiment, $30 \mathrm{mg}$ of solid $\mathrm{CX} 4 \mathrm{SO}_{3} \mathrm{HSi}(n)$ was added to $10 \mathrm{~mL}$ of deionized water. The resulting suspension was allowed to equilibrate and the titrated by dropwise addition of a $5 \times 10^{-3} \mathrm{M} \mathrm{NaOH}$ solution using phenolphthalein $(0.2 \%)$ as the $\mathrm{pH}$ indicator [24].

\subsubsection{Acidity determination in non-aqueous media}

The catalyst acidity of $\mathrm{CX}_{4} \mathrm{SO}_{3} \mathrm{HSi}(n)$ catalyst $(50 \mathrm{mg})$ was determined by potentiometric titration of a suspension consisting of the solid catalyst in acetonitrile using a solution containing nbutylamine in acetonitrile (0.025 N) in a Metrohm 794 Basic Titrino apparatus with a double junction electrode [25].

\subsubsection{Textural properties}

The specific surface area of the solids was determined from the $\mathrm{N}_{2}$ adsorption-desorption isotherms at liquid nitrogen temperature. They were obtained using Micromeritics ASAP 2020equipment. The samples were previously degassed at $100^{\circ} \mathrm{C}$ for $12 \mathrm{~h}$. The specific surface area (SBET) was determined by the BET method. The samples were degassed prior the analyses.

\subsubsection{Thermogravimetric analysis}

The thermogravimetric analysis was performed on a PerkinElmer Simultaneous Thermal Analyzer (STA) 6000. The masses of the samples used were between 5 and $10 \mathrm{mg}$, with a heating rate of $10{ }^{\circ} \mathrm{C} \mathrm{min}-1$ under nitrogen flow. The temperatures of the thermograms were recorded at each variation of $0.1^{\circ} \mathrm{C}$ in a range of $30^{\circ} \mathrm{C}-700^{\circ} \mathrm{C}$. This technique allows to verify the loss of mass at different temperatures and verify the degree of hydration of the catalysts.

\subsubsection{Elemental analysis determination}

Elemental analyses were obtained by using a CHN PerkinElmer 2400 instrument.

\subsection{Single-crystal X-ray diffraction technique}

Room temperature X-ray diffraction intensity data were measured employing MoK $\alpha$ beam from an I $\mu$ S microsource with multilayer optics (Bruker-AXS Kappa Duo diffractometer with an APEX II CCD detector). The diffraction images were acquired upon rotation of the $\varphi$ and $\omega$ axes. After integration, reduction and scaling of raw X-ray intensity data, the structure was solved with SIR2004 [37] using direct methods of phase retrieval. The $\mathrm{Br}, \mathrm{C}, \mathrm{O}$, and $\mathrm{N}$ atoms were found directly from the solved Fourier map. In sequence, the initial model was refined by the full-matrix least squares method with SHELXL-2014 [38] on F2. Non-hydrogen and hydrogen atoms were refined with anisotropic and isotropic $\left[\mathrm{U}_{\mathrm{iso}}(\mathrm{H})=1.2 \mathrm{U}_{\mathrm{eq}}\right]$ atomic displacement parameters, respectively. Hydrogens coordinates were stereochemically calculated following a riding model $[\mathrm{C}-\mathrm{H}$ bond lengths of either $0.93 \AA$ (aromatic), $0.97 \AA$ (methylene), or $0.98 \AA$ (methine). The program ORTEP-3 [39] was used to prepare the molecular drawing. The final crystallographic information file (CIF) has been deposited with the Cambridge Structural Data Base under deposit code 1898736.

\subsection{General procedure for the synthesis of julolidines (1-12 $[( \pm)-T+C])$}

A mixture of aniline ( $0.5 \mathrm{mmol})$, formaldehyde (1.5 mmol), 2,3dihydrofuran $(1.5 \mathrm{mmol})$ and $\mathrm{CX}_{4} \mathrm{SO}_{3} \mathrm{HSi}(n)(15 \mathrm{mg}, 0.5 \mathrm{~mol} \%)$ was added to a vial sealed and placed in a CEM Discover microwave oven. The reaction mixture it was subjected to microwave irradiation for 10 min under stirring, the temperature of $150{ }^{\circ} \mathrm{C}$ and power of $50 \mathrm{~W}$, solvent-free. Subsequently, dichloromethane was added to the reaction mixture and then filtered for recovery and reuse of the solid (catalyst). The filtrate was evaporated under reduced pressure and purified by silica gel column chromatography. Twenty-four julolidines were obtained. ${ }^{1} \mathrm{H},{ }^{13} \mathrm{C}$ NMR, GC/MS and Infrared characterized all the julolidines $1-12[( \pm)-\mathrm{T}+\mathrm{C}]$.

\subsection{1. (3bR,6aR,9aR,12aR)-2-bromo-3b,5,6,6a,9a,10,11,12a-} octahydro-7H,9H-furo[3,2-c]furo[2',3':4,5]pyrido[3,2,1-ij]quinoline (( \pm$)-1 T)$

Column chromatography on silica gel (hexane/dichloromethane/ethyl acetate $=6: 2: 1 \mathrm{v} / \mathrm{v}$ ) afforded $75.3 \mathrm{mg}$ of the title product in $45 \%$ yield as a yellow solid. Mp: $111.1-112.3^{\circ} \mathrm{C} .{ }^{1} \mathrm{H}$ NMR $\left(300 \mathrm{MHz} ; \mathrm{CDCl}_{3}\right): \delta 1.83-1.95(\mathrm{~m}, 2 \mathrm{H}) ; 2.10-2.22(\mathrm{~m}, 2 \mathrm{H})$, $2.53-2.64(\mathrm{~m}, 2 \mathrm{H}), 2.81$ (dd, $J=7.6,11.4 \mathrm{~Hz}, 2 \mathrm{H}), 2.98$ (dd, $J=4.2$, $11.4 \mathrm{~Hz}, 2 \mathrm{H}), 3.79$ (td, $J=7.2,8.4 \mathrm{~Hz}, 2 \mathrm{H}) ; 3.88(\mathrm{td}, J=5.4,8.4 \mathrm{~Hz}$, $2 \mathrm{H}), 4.68(\mathrm{~d}, J=6.6 \mathrm{~Hz}, 2 \mathrm{H}), 7.36(\mathrm{~s}, 2 \mathrm{H}) .{ }^{13} \mathrm{C} \mathrm{NMR}\left(75 \mathrm{MHz} ; \mathrm{CDCl}_{3}\right)$ : $\delta 29.3\left(\mathrm{CH}_{2}\right), 36.1(\mathrm{CH}), 51.1\left(\mathrm{CH}_{2}\right), 65.8\left(\mathrm{CH}_{2}\right), 75.0(\mathrm{CH}), 110.2(\mathrm{CH})$, 124.4 (C), 133.0 (C), 142.7 (C). IR (neat): 2960, 2920, 2851, 1590, 1047, 865, 616. GC/MS m/z (abundancy \%): 335 (49, $\mathrm{M}^{+}$), 337 (46, $M+2), 292$ (100), 55 (46). 
4.5.2. (3bR,6aR,9aS,12aS)-2-bromo-3b,5,6,6a,9a,10,11,12aoctahydro-7H,9H-furo[3,2-c]furo[2',3':4,5]pyrido[3,2,1-ij]quinoline (1C)

Column chromatography on silica gel (hexane/dichloromethane/ethyl acetate $=6: 2: 1 \mathrm{v} / \mathrm{v}$ ) afforded $78.7 \mathrm{mg}$ of the title product in $47 \%$ yield as a yellow solid. Mp: $89.4-89.9{ }^{\circ} \mathrm{C}$. ${ }^{1} \mathrm{H}$ NMR $\left(300 \mathrm{MHz}, \mathrm{CDCl}_{3}\right): \delta 1.68-1.80(\mathrm{~m}, 2 \mathrm{H}) ; 2.20-2.32(\mathrm{~m}, 2 \mathrm{H})$, $2.44-2.53(\mathrm{~m}, 2 \mathrm{H}), 2.56(\mathrm{dd}, J=9.6,12 \mathrm{~Hz}, 2 \mathrm{H}), 2.94(\mathrm{dd}, J=3.8$, $9.6 \mathrm{~Hz}, 2 \mathrm{H}), 3.80(\mathrm{td}, J=6.3,9.0 \mathrm{~Hz}, 2 \mathrm{H}), 3.95(\mathrm{td}, \mathrm{J}=6.3$ e $8.4 \mathrm{~Hz}$, $2 \mathrm{H}), 4.47(\mathrm{~d}, J=4.5 \mathrm{~Hz}, 2 \mathrm{H}), 7.41(\mathrm{~s}, 2 \mathrm{H}) .{ }^{13} \mathrm{C} \mathrm{NMR}\left(75 \mathrm{MHz}, \mathrm{CDCl}_{3}\right)$ : $\delta 30.0\left(\mathrm{CH}_{2}\right), 35.3(\mathrm{CH}), 51.0\left(\mathrm{CH}_{2}\right), 65.2\left(\mathrm{CH}_{2}\right), 75.3(\mathrm{CH}), 109.8(\mathrm{CH})$, 123.7 (C), 133.6 (C), 143.2 (C). IR (neat): 2918, 2855, 2825, 1591, 1050, 871, 618. GC/MS m/z (abundancy \%): 335 (54, $\mathrm{M}^{+}$), 337 (54, $\mathrm{M}+2), 292$ (100), 55 (47).

\subsection{3. (3bR,6aR,9aR,12aR)-2-chloro-3b,5,6,6a,9a,10,11,12a-} octahydro-7H,9H-furo[3,2-c]furo[2',3':4,5]pyrido[3,2,1-ij]quinoline (( \pm$)-2 T)$

Column chromatography on silica gel (dichloromethane/ethyl acetate $=2: 0.1 \mathrm{v} / \mathrm{v}$ ) afforded $69.8 \mathrm{mg}$ of the title product in $48 \%$ yield as a brown solid. Mp: $104.3-104.8^{\circ} \mathrm{C} .{ }^{1} \mathrm{H}$ NMR $(300 \mathrm{MHz}$, $\left.\mathrm{CDCl}_{3}\right): \delta 1.83-1.95(\mathrm{~m}, 2 \mathrm{H}), 2.10-2.22(\mathrm{~m}, 2 \mathrm{H}), 2.54-2.64(\mathrm{~m}, 2 \mathrm{H})$, $2.81(\mathrm{dd}, \mathrm{J}=7.5,11.4,2 \mathrm{H}), 2.98(\mathrm{dd}, J=4.2,11.4 \mathrm{~Hz}, 2 \mathrm{H}), 3.79(\mathrm{td}$, $J=7.5,8.4 \mathrm{~Hz}, 2 \mathrm{H}), 3.88(\mathrm{td}, J=5.4,8.4 \mathrm{~Hz}, 2 \mathrm{H}), 4.68(\mathrm{~d}, J=6.6 \mathrm{~Hz}$, $2 \mathrm{H}), 7.22(\mathrm{~s}, 2 \mathrm{H}) .{ }^{13} \mathrm{C}$ NMR $\left(75 \mathrm{MHz}, \mathrm{CDCl}_{3}\right): \delta 29.4\left(\mathrm{CH}_{2}\right), 36.2(\mathrm{CH})$, $51.2\left(\mathrm{CH}_{2}\right), 65.8\left(\mathrm{CH}_{2}\right), 75.0(\mathrm{CH}), 122.9(\mathrm{CH}), 124.0(\mathrm{C}), 130.2(\mathrm{C})$ 142.3 (C). IR (neat): 2933, 2891, 2858, 2823, 1487, 1452, 1052, 860, 637. GC/MS $m / z$ (abundancy \%): $291\left(62, \mathrm{M}^{+}\right), 246$ (100), 55 (42).

\subsection{4. (3bR,6aR,9aS,12aS)-2-chloro-3b,5,6,6a,9a,10,11,12a-} octahydro-7H,9H-furo[3,2-c]furo[2',3':4,5]pyrido[3,2,1-ij]quinoline (2C)

Column chromatography on silica gel (dichloromethane/ethyl acetate $=2: 0.1 \mathrm{v} / \mathrm{v}$ ) afforded $66.9 \mathrm{mg}$ of the title product in $46 \%$ yield as a brown solid. Mp: $83.6-84.5^{\circ} \mathrm{C} .{ }^{1} \mathrm{H}$ NMR $(300 \mathrm{MHz}$, $\left.\mathrm{CDCl}_{3}\right): \delta 1.67-1.77(\mathrm{~m}, 2 \mathrm{H}), 2.20-2.32(\mathrm{~m}, 2 \mathrm{H}), 2.47-2.57(\mathrm{~m}, 2 \mathrm{H})$, $2.57-2.61(\mathrm{~m}, 2 \mathrm{H}), 2.93(\mathrm{dd}, J=3.6,9.6 \mathrm{~Hz}, 2 \mathrm{H}), 3.80(\mathrm{td}, J=6.0$, $8.9 \mathrm{~Hz}, 2 \mathrm{H}), 3.94(\mathrm{td}, J=6.0,8.4 \mathrm{~Hz}, 2 \mathrm{H}), 4.46(\mathrm{~d}, \mathrm{~J}=4.8,2 \mathrm{H}), 7.27(\mathrm{~s}$, $2 \mathrm{H}) .{ }^{13} \mathrm{C}$ NMR (75 MHz, $\left.\mathrm{CDCl}_{3}\right): \delta 30.0\left(\mathrm{CH}_{2}\right), 35.4(\mathrm{CH}), 51.1\left(\mathrm{CH}_{2}\right)$, $65.2\left(\mathrm{CH}_{2}\right), 75.3(\mathrm{CH}), 122.6(\mathrm{CH}), 123.3(\mathrm{C}), 130.7(\mathrm{C}), 142.8(\mathrm{C}) . \mathrm{IR}$ (neat): 2926, 2865, 2828, 2803, 1490, 1452, 1049, 856, 644. GC/MS $\mathrm{m} / \mathrm{z}$ (abundancy \%): $291\left(65, \mathrm{M}^{+}\right), 246$ (100), 55 (40).

4.5.5. (3bR,6aR,9aR,12aR)-2-fluoro-3b,5,6,6a,9a,10,11,12aoctahydro-7H,9H-furo[3,2-c]furo[2',3':4,5]pyrido[3,2,1-ij]quinoline (( \pm$)-3 T)$

Column chromatography on silica gel (dichloromethane/ethyl acetate $=2: 0.1 \mathrm{v} / \mathrm{v}$ ) afforded $70.1 \mathrm{mg}$ of the title product in $51 \%$ yield as a brown solid. Mp: $115.8-116.4^{\circ} \mathrm{C} .{ }^{1} \mathrm{H}$ NMR $(300 \mathrm{MHz}$, $\left.\mathrm{CDCl}_{3}\right): \delta 1.86-1.97(\mathrm{~m}, 2 \mathrm{H}), 2.10-2.21(\mathrm{~m}, 2 \mathrm{H}), 2.55-2.66(\mathrm{~m}, 2 \mathrm{H})$, 2.78 (dd, $J=7.5,11.4 \mathrm{~Hz}, 2 \mathrm{H}), 2.95$ (dd, $J=4.2,11.4 \mathrm{~Hz}, 2 \mathrm{H}), 3.79$ (td, $J=7.2,8.4 \mathrm{~Hz}, 2 \mathrm{H}), 3.87(\mathrm{td}, J=5.4,8.4 \mathrm{~Hz}, 2 \mathrm{H}), 4.70(\mathrm{~d}, J=6.6 \mathrm{~Hz}$, $2 \mathrm{H}), 6.99(\mathrm{~d}, J=8.7 \mathrm{~Hz}, 2 \mathrm{H}) .{ }^{13} \mathrm{C} \mathrm{NMR}\left(75 \mathrm{MHz}, \mathrm{CDCl}_{3}\right): \delta 29.4\left(\mathrm{CH}_{2}\right)$, $36.4(\mathrm{CH}), 51.6\left(\mathrm{CH}_{2}\right), 65.9\left(\mathrm{CH}_{2}\right), 75.2\left(\mathrm{~d}, \mathrm{~J}_{\mathrm{C}-\mathrm{F}}=1.5 \mathrm{~Hz}, \mathrm{CH}\right), 116.8(\mathrm{~d}$, $\left.\mathrm{J}_{\mathrm{C}-\mathrm{F}}=21.8 \mathrm{~Hz}, \mathrm{CH}\right), 124.0$ (d, J $\left.\mathrm{C}-\mathrm{F}=6.4 \mathrm{~Hz}, \mathrm{C}\right), 140.5$ (d, JC-F $=1.5 \mathrm{~Hz}$, C), 155.7 (d, JC-F $=236.3 \mathrm{~Hz}, \mathrm{C}$ ). IR (neat): 2937, 2868, 2827, 1493, 1284, 855, 701. GC/MS m/z (abundancy \%): 275 (61, $\mathrm{M}^{+}$), 230 (100), 55 (34).

4.5.6. (3bR,6aR,9aS,12aS)-2-fluoro-3b,5,6,6a,9a,10,11,12aoctahydro-7H,9H-furo[3,2-c]furo[2',3':4,5]pyrido[3,2,1-ij]quinoline (3C)

Column chromatography on silica gel (dichloromethane/ethyl acetate $=2: 0.1 \mathrm{v} / \mathrm{v}$ ) afforded $63.2 \mathrm{mg}$ of the title product in $46 \%$ yield as a brown solid. Mp: $93.6-94.2{ }^{\circ} \mathrm{C} .{ }^{1} \mathrm{H}$ NMR $(300 \mathrm{MHz}$,
$\left.\mathrm{CDCl}_{3}\right): \delta 1.69-1.77(\mathrm{~m}, 2 \mathrm{H}), 2.21-2.32(\mathrm{~m}, 2 \mathrm{H}), 2.47-2.58(\mathrm{~m}, 2 \mathrm{H})$, $2.52(\mathrm{dd}, J=7.5,11.4 \mathrm{~Hz}, 2 \mathrm{H}), 2.95(\mathrm{dd}, J=4.2,11.4 \mathrm{~Hz}, 2 \mathrm{H}), 3.80$ (td, $J=6.0,8.9 \mathrm{~Hz}, 2 \mathrm{H}), 3.95(\mathrm{td}, J=6.0,8.4 \mathrm{~Hz}, 2 \mathrm{H}), 4.49$ (d, $J=3.9 \mathrm{~Hz}$, $2 \mathrm{H}), 4.04(\mathrm{~d}, J=8.7 \mathrm{~Hz}, 2 \mathrm{H}) .{ }^{13} \mathrm{C} \mathrm{NMR}\left(75 \mathrm{MHz}, \mathrm{CDCl}_{3}\right): \delta 30.1\left(\mathrm{CH}_{2}\right)$, 35.6 $(\mathrm{CH}), 51.6\left(\mathrm{CH}_{2}\right), 65.3\left(\mathrm{CH}_{2}\right), 75.6\left(\mathrm{~d}, \mathrm{~J}_{\mathrm{C}-\mathrm{F}}=1.3 \mathrm{~Hz}, \mathrm{CH}\right), 117.3(\mathrm{~d}$, $\left.\mathrm{J}_{\mathrm{C}-\mathrm{F}}=21.8 \mathrm{~Hz}, \mathrm{CH}\right), 123.3\left(\mathrm{~d}, \mathrm{~J}_{\mathrm{C}-\mathrm{F}}=6.6 \mathrm{~Hz}, \mathrm{C}\right), 140.7\left(\mathrm{~d}, \mathrm{~J}_{\mathrm{C}-\mathrm{F}}=1.7 \mathrm{~Hz}, \mathrm{C}\right)$ 155.4 (d, JC-F $=236.5$, C). IR (neat): 2933, 2869, 2825, 1492, 1282, 864, 714. GC/MS $m / z$ (abundancy \%): $275\left(63, \mathrm{M}^{+}\right), 230$ (100), 55 (34).

4.5.7. (3bR,6aR,9aR,12aR)-2-iodo-3b,5,6,6a,9a,10,11,12a-octahydro7H,9H-furo[3,2-c]furo[2',3':4,5]pyrido[3,2,1-ij]quinoline (( \pm$)-4 T)$

Column chromatography on silica gel (hexane/dichloromethane/ethyl acetate $=6: 2: 1 \mathrm{v} / \mathrm{v}$ ) afforded $80.4 \mathrm{mg}$ of the title product in $42 \%$ yield as a brown solid. Mp: $109.7-110.4{ }^{\circ} \mathrm{C} .{ }^{1} \mathrm{H}$ NMR $\left(300 \mathrm{MHz}, \mathrm{CDCl}_{3}\right): \delta 1.82-1.93(\mathrm{~m}, 2 \mathrm{H}), 2.10-2.21(\mathrm{~m}, 2 \mathrm{H})$, $2.51-2.62(\mathrm{~m}, 2 \mathrm{H}), 2.81$ (dd, $J=7.6,11.4 \mathrm{~Hz}, 2 \mathrm{H}), 2.98$ (dd, $J=4.5$, $11.4 \mathrm{~Hz}, 2 \mathrm{H}), 3.78(\mathrm{td}, J=7.5,8.4 \mathrm{~Hz}, 2 \mathrm{H}), 3.87(\mathrm{td}, J=5.4,8.4 \mathrm{~Hz}$, $2 \mathrm{H}), 5.16(\mathrm{~d}, J=6.3 \mathrm{~Hz}, 2 \mathrm{H}), 7.52(\mathrm{~s}, 2 \mathrm{H}) .{ }^{13} \mathrm{C} \mathrm{NMR}\left(75 \mathrm{MHz} ; \mathrm{CDCl}_{3}\right)$ : $\delta 29.3\left(\mathrm{CH}_{2}\right), 36.0(\mathrm{CH}), 51.0\left(\mathrm{CH}_{2}\right), 65.8\left(\mathrm{CH}_{2}\right), 74.8(\mathrm{CH}), 79.6(\mathrm{CH})$, 124.8 (C), 138.9 (C), 143.3 (C). IR (neat): 2912, 2864, 1584, 1489, 1453, 1294, 1034, 732. GC/MS $m / z$ (abundancy \%): $383\left(100, \mathrm{M}^{+}\right)$, 338 (98), 55 (24).

4.5.8. (3bR,6aR,9aS,12aS)-2-iodo-3b,5,6,6a,9a,10,11,12a-octahydro7H,9H-furo[3,2-c]furo[2',3':4,5]pyrido[3,2,1-ij]quinoline (4C)

Column chromatography on silica gel (hexane/dichloromethane/ethyl acetate $=6: 2: 1 \mathrm{v} / \mathrm{v}$ ) afforded $78.5 \mathrm{mg}$ of the title product in $41 \%$ yield as a brown solid. Mp: $87.1-87.8^{\circ} \mathrm{C}$. ${ }^{1} \mathrm{H}$ NMR $\left(300 \mathrm{MHz}, \mathrm{CDCl}_{3}\right)$ : $\delta 1.67-1.76(\mathrm{~m}, 2 \mathrm{H}), 2.20-2.32(\mathrm{~m}, 2 \mathrm{H})$, $2.40-2.53(\mathrm{~m}, 2 \mathrm{H}), 2.56(\mathrm{dd}, J=10.2,12.0 \mathrm{~Hz}, 2 \mathrm{H}), 2.93(\mathrm{dd}, J=4.2$, $10.2 \mathrm{~Hz}, 2 \mathrm{H}), 3.79(\mathrm{td}, J=6.0,8.2 \mathrm{~Hz}, 2 \mathrm{H}), 3.97(\mathrm{td}, J=6.0,8.8 \mathrm{~Hz}$, $2 \mathrm{H}), 4.45(\mathrm{~d}, J=4.5 \mathrm{~Hz}, 2 \mathrm{H}), 7.60(\mathrm{~s}, 2 \mathrm{H}) .{ }^{13} \mathrm{C} \mathrm{NMR}\left(75 \mathrm{MHz}, \mathrm{CDCl}_{3}\right)$ : $\delta 30.0\left(\mathrm{CH}_{2}\right), 35.3(\mathrm{CH}), 50.9\left(\mathrm{CH}_{2}\right), 65.1\left(\mathrm{CH}_{2}\right), 75.2(\mathrm{CH}), 79.1(\mathrm{CH})$, 124.1 (C), 139.4 (C), 143.8 (C). IR (neat): 2928, 2871, 1587, 1489, 1448, 1292, 1051, 731. GC/MS $m / z$ (abundancy \%): 383 (100, $\mathrm{M}^{+}$), 338 (83), 55 (19).

4.5.9. (3bR,6aR,9aR,12aR)-3b,5,6,6a,9a,10,11,12a-octahydro-7H,9Hfuro[3,2-c]furo[2',3':4,5]pyrido[3,2,1-ij]quinoline (( \pm$)-5 T)$

Column chromatography on silica gel (hexane/dichloromethane/ethyl acetate $=3: 2: 1 \mathrm{v} / \mathrm{v}$ ) afforded $52.6 \mathrm{mg}$ of the title product in $41 \%$ yield as a yellow solid. Mp: $139.3-139.9{ }^{\circ} \mathrm{C}$. ${ }^{1} \mathrm{H}$ NMR $\left(300 \mathrm{MHz}, \mathrm{CDCl}_{3}\right): \delta 1.80-2.01(\mathrm{~m}, 2 \mathrm{H}), 2.09-2.26(\mathrm{~m}, 2 \mathrm{H})$, 2.52-3.34 (m, 2H), 2.75-2.91 (m, 2H), 2.94-3.09 (m, 2H), 3.65-4.06 (m, $4 \mathrm{H}), 4.77(\mathrm{~d}, J=6.4 \mathrm{~Hz}, 2 \mathrm{H}), 6,80(\mathrm{t}, J=7.4 \mathrm{~Hz}, 1 \mathrm{H})$, $7.28(\mathrm{~d}, J=7.4 \mathrm{~Hz}, 2 \mathrm{H}) .{ }^{13} \mathrm{C} \mathrm{NMR}\left(75 \mathrm{MHz}, \mathrm{CDCl}_{3}\right): \delta 29.5\left(\mathrm{CH}_{2}\right), 36.2$ $\left(\mathrm{CH}_{2}\right), 51.4\left(\mathrm{CH}_{2}\right), 65.7\left(\mathrm{CH}_{2}\right), 75.5(\mathrm{CH}), 118.2(\mathrm{C}), 122.2(\mathrm{CH}), 130.6$ (CH), 143.8 (C). IR (neat): 2927, 2856, 2821, 1487, 1446, 1292, 1047, 749. GC/MS $m / z$ (abundancy \%): $257\left(43, \mathrm{M}^{+}\right), 212$ (100), 55 (53).

\subsubsection{0. (3bR,6aR,9aS,12aS)-3b,5,6,6a,9a,10,11,12a-octahydro-} 7H,9H-furo[3,2-clfuro[2',3':4,5]pyrido[3,2,1-ij]quinoline (5C)

Column chromatography on silica gel (hexane/dichloromethane/ethyl acetate $=3: 2: 1 \mathrm{v} / \mathrm{v}$ ) afforded $46.2 \mathrm{mg}$ of the title product in $36 \%$ yield as a yellow solid. Mp: $116.5-117.4{ }^{\circ} \mathrm{C} .{ }^{1} \mathrm{H}$ NMR $\left(300 \mathrm{MHz}, \mathrm{CDCl}_{3}\right): \delta 1.62-1.85(\mathrm{~m}, 2 \mathrm{H}), 2.15-2.40(\mathrm{~m}, 2 \mathrm{H})$, 2.42-2.74 (m, 2H), 2.88-3.03 (2H), 3.72-4.08 (m, 4H), $4.55(\mathrm{~d}$, $J=4.4 \mathrm{~Hz}, 2 \mathrm{H}), 6.82(\mathrm{t}, J=7.6 \mathrm{~Hz}, 1 \mathrm{H}), 7.33(\mathrm{~d}, J=7.6 \mathrm{~Hz}, 2 \mathrm{H}) .{ }^{13} \mathrm{C}$ $\operatorname{NMR}\left(75 \mathrm{MHz}, \mathrm{CDCl}_{3}\right): \delta 30.1\left(\mathrm{CH}_{2}\right), 35.3\left(\mathrm{CH}_{2}\right), 51.2\left(\mathrm{CH}_{2}\right), 65.0$ $\left(\mathrm{CH}_{2}\right), 75.8(\mathrm{CH}), 118.0(\mathrm{C}), 121.5(\mathrm{CH}), 131.2(\mathrm{CH}), 144.0(\mathrm{C})$. IR (neat): $2928,2852,2826,1489,1447,1291,1051,753$. GC/MS $m / z$ (abundancy \%): 257 (49, $\left.\mathrm{M}^{+}\right), 212$ (100), 55 (74). 
4.5.11. Butyl-(3bR,6aR,9aR,12aR)-3b,5,6,6a,9a,10,11,12a-octahydro7H,9H-furo[3,2-c]furo[2',3':4,5]pyrido[3,2,1-ij]quinoline-2carboxylate (( \pm$)-6 T)$

Column chromatography on silica gel (hexane/dichloromethane/ethyl acetate $=2: 2: 1 \mathrm{v} / \mathrm{v}$ ) afforded $58.9 \mathrm{mg}$ of the title product in $33 \%$ yield as a brown oil. ${ }^{1} \mathrm{H}$ NMR $\left(300 \mathrm{MHz}, \mathrm{CDCl}_{3}\right)$ : $\delta 0.94(\mathrm{t}, J=7.5 \mathrm{~Hz}, 3 \mathrm{H}), 1.36-1.49(\mathrm{~m}, 2 \mathrm{H}), 1.64-1.74(\mathrm{~m}, 2 \mathrm{H})$, 1.80-1.91 (m, 2H), 2.13-2.24 (m, 2H), 2.50-2.61 (m, 2H), 2.93 (dd, $J=8.1,11.7 \mathrm{~Hz}, 2 \mathrm{H}), 3.08$ (dd, $J=4.8,11.7 \mathrm{~Hz}, 2 \mathrm{H}), 3.82$ (td, $J=6.9$, $8.4 \mathrm{~Hz}, 2 \mathrm{H}), 3.89(\mathrm{td}, J=5.4,8.4 \mathrm{~Hz}, 2 \mathrm{H}), 4.23(\mathrm{t}, J=6.6 \mathrm{~Hz}, 2 \mathrm{H}), 4.72$ $(\mathrm{d}, J=6.0 \mathrm{~Hz}, 2 \mathrm{H}), 7.94(\mathrm{~s}, 2 \mathrm{H}) .{ }^{13} \mathrm{C}$ NMR $\left(75 \mathrm{MHz} ; \mathrm{CDCl}_{3}\right): \delta 13.7$ $\left(\mathrm{CH}_{3}\right), 19.2\left(\mathrm{CH}_{2}\right), 29.4\left(\mathrm{CH}_{2}\right), 30.8\left(\mathrm{CH}_{2}\right), 35.5(\mathrm{CH}), 50.7\left(\mathrm{CH}_{2}\right), 64.1$ $\left(\mathrm{CH}_{2} \mathrm{O}\right), 65.5\left(\mathrm{CH}_{2}\right), 75.2(\mathrm{CH}), 119.2(\mathrm{C}), 120.8(\mathrm{C}), 132.6(\mathrm{CH}), 146.9$ (C), $166.6(C=O)$. IR (neat): 2957, 2933, 2872, 1701, 1610, 1296, 1195, 769, 733. GC/MS $m / z$ (abundancy \%): $357\left(63, \mathrm{M}^{+}\right), 312$ (93), 55 (100).

4.5.12. Butyl-(3bR,6aR,9aS,12aS)-3b,5,6,6a,9a,10,11,12a-octahydro7H,9H-furo[3,2-c]furo[2',3':4,5]pyrido[3,2,1-ij]quinoline-2-

carboxylate $(\mathbf{6 C})$

Column chromatography on silica gel (hexane/dichloromethane/ethyl acetate $=2: 2: 1 \mathrm{v} / \mathrm{v}$ ) afforded $44.6 \mathrm{mg}$ of the title product in $25 \%$ yield as a brown oil. ${ }^{1} \mathrm{H}$ NMR $\left(300 \mathrm{MHz}, \mathrm{CDCl}_{3}\right)$ : $\delta 0.94(\mathrm{t}, J=7.5 \mathrm{~Hz}, 3 \mathrm{H}), 1.43$ (sext, $J=7.5 \mathrm{~Hz}, 2 \mathrm{H}), 1.65-1.77(\mathrm{~m}, 4 \mathrm{H})$, $2.21-2.34(\mathrm{~m}, 2 \mathrm{H}), 2.42-2.52(\mathrm{~m}, 2 \mathrm{H}), 2.72(\mathrm{t}, J=11.5 \mathrm{~Hz}, 2 \mathrm{H}), 2.98$ $(\mathrm{dd}, J=5.4,11.1 \mathrm{~Hz}, 2 \mathrm{H}), 3.83(\mathrm{td}, J=6.3,9.0 \mathrm{~Hz}, 2 \mathrm{H}), 3.96(\mathrm{td}, J=6.3$, $8.4 \mathrm{~Hz}, 2 \mathrm{H}), 4.24$ (t, $J=6.6 \mathrm{~Hz}, 2 \mathrm{H}), 4.52(\mathrm{~d}, J=4.8 \mathrm{~Hz}, 2 \mathrm{H}), 7.98$ (s, $2 \mathrm{H}) .{ }^{13} \mathrm{C}$ NMR $\left(75 \mathrm{MHz} ; \mathrm{CDCl}_{3}\right): \delta 13.8\left(\mathrm{CH}_{3}\right), 19.2\left(\mathrm{CH}_{2}\right), 29.9\left(\mathrm{CH}_{2}\right)$, $30.9\left(\mathrm{CH}_{2}\right), 34.8(\mathrm{CH}), 50.4\left(\mathrm{CH}_{2}\right), 64.2\left(\mathrm{CH}_{2} \mathrm{O}\right), 65.9\left(\mathrm{CH}_{2}\right), 75.6(\mathrm{CH})$, $118.9(\mathrm{C}), 120.2(\mathrm{C}), 133.1(\mathrm{CH}), 147.5(\mathrm{C}), 166.5(\mathrm{C}=\mathrm{O})$. IR (neat): 2956, 2933, 2872, 1701, 1612, 1295, 1194, 768, 733. GC/MS m/z (abundancy \%): 357 (67, M+), 312 (88), 55 (100).

4.5.13. (3bR,6aR,9aR,12aR)-2-(tert-butyl)-3b,5,6,6a,9a,10,11,12aoctahydro-7H,9H-furo[3,2-c]furo[2',3':4,5]pyrido[3,2,1-ij]quinoline $(( \pm)-7 T)$

Column chromatography on silica gel (hexane/dichloromethane/ethyl acetate $=2: 1: 0.3 \mathrm{v} / \mathrm{v}$ ) afforded $65.7 \mathrm{mg}$ of the title product in $42 \%$ yield as a white solid. Mp: $120.7-121.4{ }^{\circ} \mathrm{C} .{ }^{1} \mathrm{H}$ NMR $\left(300 \mathrm{MHz}, \mathrm{CDCl}_{3}\right): \delta 1.29(\mathrm{~s}, 9 \mathrm{H}), 1.88-1.99(\mathrm{~m}, 2 \mathrm{H}), 2.11-2.22(\mathrm{~m}$, $2 \mathrm{H}), 2.57-2.69(\mathrm{~m}, 2 \mathrm{H}), 2.81(\mathrm{dd}, J=7.5,11.2 \mathrm{~Hz}, 2 \mathrm{H}), 2.97$ (dd, $J=4.2,11.2 \mathrm{~Hz}, 2 \mathrm{H}), 3.80$ (td, $J=7.2,8.4 \mathrm{~Hz}, 2 \mathrm{H}), 3.91$ (td, $J=5.1$, $8.4 \mathrm{~Hz}, 2 \mathrm{H}), 4.76(\mathrm{~d}, J=6.6 \mathrm{~Hz}, 2 \mathrm{H}), 7.31(\mathrm{~s}, 2 \mathrm{H}) .{ }^{13} \mathrm{C} \mathrm{NMR}(75 \mathrm{MHz}$, $\left.\mathrm{CDCl}_{3}\right): \delta 29.6(\mathrm{CH} 3), 31.4\left(\mathrm{CH}_{2}\right), 33.9(\mathrm{C}), 36.43(\mathrm{CH}), 51.8\left(\mathrm{CH}_{2}\right), 65.8$ $\left(\mathrm{CH}_{2}\right), 75.8(\mathrm{CH}), 122.0(\mathrm{C}), 127.7(\mathrm{CH}), 141.6(\mathrm{C}), 145.18(\mathrm{C})$. IR (neat): 2951, 2868, 2798, 1368, 874, 769. GC/MS $m / z$ (abundancy \%): 313 (32, M+), 298 (100).

4.5.14. (3bR,6aR,9aS,12aS)-2-(tert-butyl)-3b,5,6,6a,9a,10,11,12aoctahydro-7H,9Hfuro[3,2-c]furo[2',3':4,5]pyrido[3,2,1-ij]quinoline (7C)

Column chromatography on silica gel (hexane/dichloromethane/ethyl acetate $=2: 1: 0.3 \mathrm{v} / \mathrm{v}$ ) afforded $62.6 \mathrm{mg}$ of the title product in $40 \%$ yield as a white solid. $\mathrm{Mp}$ : 93.6-94.2 ${ }^{\circ} \mathrm{C} .{ }^{1} \mathrm{H}$ NMR $\left(300 \mathrm{MHz}, \mathrm{CDCl}_{3}\right): \delta 1.29(\mathrm{~s}, 9 \mathrm{H}), 1.88-1.99(\mathrm{~m}, 2 \mathrm{H}), 2.11-2.22(\mathrm{~m}$, $2 \mathrm{H}), 2.57-2.69(\mathrm{~m}, 2 \mathrm{H}), 2.81(\mathrm{dd}, J=7.5,11.2 \mathrm{~Hz}, 2 \mathrm{H}), 2.97(\mathrm{dd}$, $J=4.2,11.2 \mathrm{~Hz}, 2 \mathrm{H}), 3.80$ (td, $J=7.2,8.4 \mathrm{~Hz}, 2 \mathrm{H}), 3.91$ (td, $J=5.1$, $8.4 \mathrm{~Hz}, 2 \mathrm{H}), 4.76(\mathrm{~d}, J=6.6 \mathrm{~Hz}, 2 \mathrm{H}), 7.31(\mathrm{~s}, 2 \mathrm{H}) .{ }^{13} \mathrm{C} \mathrm{NMR}(75 \mathrm{MHz}$, $\left.\mathrm{CDCl}_{3}\right): \delta 29.6(\mathrm{CH} 3), 31.4\left(\mathrm{CH}_{2}\right), 33.9(\mathrm{C}), 36.43(\mathrm{CH}), 51.8\left(\mathrm{CH}_{2}\right), 65.8$ $\left(\mathrm{CH}_{2}\right), 75.8(\mathrm{CH}), 122.0(\mathrm{C}), 127.7(\mathrm{CH}), 141.6(\mathrm{C}), 145.18(\mathrm{C})$. IR (neat): 2946, 2856, 2819, 1367, 874, 710. GC/MS $m / z$ (abundancy \%): 313 (31, M+), 298 (100).
4.5.15. (3bR,6aR,9aR,12aR)-2-methyl-3b,5,6,6a,9a,10,11,12aoctahydro-7H,9H-furo[3,2-c]furo[2',3':4,5]pyrido[3,2,1-ij]quinoline $(( \pm)-8 T)$

Column chromatography on silica gel (hexane/dichloromethane/ethyl acetate $=3: 2: 1 \mathrm{v} / \mathrm{v}$ ) afforded $56.9 \mathrm{mg}$ of the title product in $42 \%$ yield as a yellow solid. Mp: $112.9-113.6{ }^{\circ} \mathrm{C} .{ }^{1} \mathrm{H}$ NMR $\left(300 \mathrm{MHz}, \mathrm{CDCl}_{3}\right): \delta 1.87-1.98(\mathrm{~m}, 2 \mathrm{H}), 2.10-2.19(\mathrm{~m}, 2 \mathrm{H}), 2.23(\mathrm{~s}$, $3 \mathrm{H}), 2.56-2.66(\mathrm{~m}, 2 \mathrm{H}), 2.77(\mathrm{dd}, J=7.8,11.1 \mathrm{~Hz}, 2 \mathrm{H}), 2.94(\mathrm{dd}$ $J=4.2,11.1 \mathrm{~Hz}, 2 \mathrm{H}), 3.79(\mathrm{td}, J=7.5,8.4 \mathrm{~Hz}, 2 \mathrm{H}), 3.89(\mathrm{td}, J=5.4$, $8.4 \mathrm{~Hz}, 2 \mathrm{H}), 4.74(\mathrm{~d}, J=6.6 \mathrm{~Hz}, 2 \mathrm{H}), 7.09(\mathrm{~s}, 2 \mathrm{H}) .{ }^{13} \mathrm{C} \mathrm{NMR}(75 \mathrm{MHz}$, $\left.\mathrm{CDCl}_{3}\right): \delta 29.5(\mathrm{CH} 3), 36.6\left(\mathrm{CH}_{2}\right), 52.0(\mathrm{CH}), 55.7\left(\mathrm{CH}_{2}\right), 66.0\left(\mathrm{CH}_{2}\right)$, $75.6(\mathrm{CH}), 116.1(\mathrm{C}), 123.8(\mathrm{C}), 138.3(\mathrm{CH}), 152.3(\mathrm{C})$. IR (neat): 2927, 2863, 2824, 1495, 1888, 1051, 863, 700. GC/MS m/z (abundancy \%): 271 (66, M+), 226 (100), 55 (16).

4.5.16. (3bR,6aR,9aS,12aS)-2-methyl-3b,5,6,6a,9a,10,11,12aoctahydro-7H,9H-furo[3,2-c]furo[2',3':4,5]pyrido[3,2,1-ij]quinoline (8C)

Column chromatography on silica gel (hexane/dichloromethane/ethyl acetate $=3: 2: 1 \mathrm{v} / \mathrm{v}$ ) afforded $52.8 \mathrm{mg}$ of the title product in $39 \%$ yield as a yellow solid. Mp: 91.6-92.1 ${ }^{\circ} \mathrm{C} .{ }^{1} \mathrm{H}$ NMR $\left(300 \mathrm{MHz}, \mathrm{CDCl}_{3}\right): \delta 1.67-1.76(\mathrm{~m}, 2 \mathrm{H}), 2.17-2.33(\mathrm{~m}, 2 \mathrm{H}), 2.24(\mathrm{~s}$, $3 \mathrm{H}), 2.46-2.58(\mathrm{~m}, 2 \mathrm{H}), 2.53(\mathrm{dd}, J=12.1,6.0 \mathrm{~Hz}, 2 \mathrm{H}), 2.91(\mathrm{dd}$, $J=12.1,17.8 \mathrm{~Hz}, 2 \mathrm{H}), 3.81(\mathrm{td}, J=6.0,8.1 \mathrm{~Hz}, 2 \mathrm{H}), 3.96(\mathrm{td}, J=6.0$, $8.9 \mathrm{~Hz}, 2 \mathrm{H}), 4.51(\mathrm{~d}, J=3.3 \mathrm{~Hz}, 2 \mathrm{H}), 7.15(\mathrm{~s}, 2 \mathrm{H}) .{ }^{13} \mathrm{C} \mathrm{NMR}(75 \mathrm{MHz}$, $\left.\mathrm{CDCl}_{3}\right): \delta 20.2\left(\mathrm{CH}_{3}\right), 30.2\left(\mathrm{CH}_{2}\right), 35.5(\mathrm{CH}), 51.5\left(\mathrm{CH}_{2}\right), 65.1\left(\mathrm{CH}_{2}\right)$, $75.8(\mathrm{CH}), 121.6(\mathrm{C}), 127.3(\mathrm{C}), 131.6(\mathrm{CH}), 141.9(\mathrm{C})$. IR (neat): 2929, $2860,2825,1495,1287,1055,825,732$. GC/MS $m / z$ (abundancy \%): $271(73, \mathrm{M}+), 226$ (100), 55 (15).

4.5.17. (3bR,6aR,9aR,12aR)-3b,5,6,6a,9a,10,11,12a-octahydro7H,9H-furo[3,2-c]furo[2',3':4,5]pyrido[3,2,1-ij]quinoline-2carbonitrile $(( \pm)-9 T)$

Column chromatography on silica gel (hexane/dichloromethane/ethyl acetate $=2: 2: 0.5 \mathrm{v} / \mathrm{v}$ ) afforded $57.8 \mathrm{mg}$ of the title product in $41 \%$ yield as a yellow oil. ${ }^{1} \mathrm{H}$ NMR $\left(300 \mathrm{MHz}, \mathrm{CDCl}_{3}\right)$ : $\delta 1.79-1.90(\mathrm{~m}, 2 \mathrm{H}), 2.12-2.25(\mathrm{~m}, 2 \mathrm{H}), 2.49-2.60(\mathrm{~m}, 2 \mathrm{H}), 2.95(\mathrm{dd}$, $J=8.1,12.0 \mathrm{~Hz}, 2 \mathrm{H}), 3.12(\mathrm{dd}, J=4.8,12.0 \mathrm{~Hz}, 2 \mathrm{H}), 3.82(\mathrm{td}, J=6.9$, $8.4 \mathrm{~Hz}, 2 \mathrm{H}), 3.89(\mathrm{td}, J=5.4,8.4 \mathrm{~Hz}, 2 \mathrm{H}), 4.65(\mathrm{~d}, J=6.0 \mathrm{~Hz}, 2 \mathrm{H}), 7.49$ (s, 2H). ${ }^{13} \mathrm{C}$ NMR $\left(75 \mathrm{MHz} ; \mathrm{CDCl}_{3}\right): \delta 29.2\left(\mathrm{CH}_{2}\right), 35.2(\mathrm{CH}), 50.3$ $\left(\mathrm{CH}_{2}\right), 65.6\left(\mathrm{CH}_{2}\right), 74.5(\mathrm{CH}), 99.3(\mathrm{C}), 119.9(\mathrm{CN}), 121.9(\mathrm{C}), 134.5$ (CH), 146.2 (C). IR (neat): 2933, 2872, 2839, 2209, 1609, 1510, 1292, 1054, 734. GC/MS $m / z$ (abundancy \%): $282\left(39, \mathrm{M}^{+}\right), 237$ (100), 55 (30).

\subsubsection{8. (3bR,6aR,9aS,12aS)-3b,5,6,6a,9a,10,11,12a-octahydro-} 7H,9H-furo[3,2-c]furo[2',3':4,5]pyrido[3,2,1-ij]quinoline-2carbonitrile (9C)

Column chromatography on silica gel (hexane/dichloromethane/ethyl acetate $=2: 2: 0.5 \mathrm{v} / \mathrm{v}$ ) afforded $60.6 \mathrm{mg}$ of the title product in $43 \%$ yield as a yellow oil. ${ }^{1} \mathrm{H}$ NMR $\left(300 \mathrm{MHz}, \mathrm{CDCl}_{3}\right)$ : $\delta 1.69-1.78(\mathrm{~m}, 2 \mathrm{H}), 2.21-2.34(\mathrm{~m}, 2 \mathrm{H}), 2.41-2.52(\mathrm{~m}, 2 \mathrm{H}), 2.72(\mathrm{dd}$, $J=12.0,11.4 \mathrm{~Hz}, 2 \mathrm{H}), 3.02(\mathrm{dd}, J=5.1,11.4 \mathrm{~Hz}, 2 \mathrm{H}), 3.82(\mathrm{td}, J=5.7$, $8.7 \mathrm{~Hz}, 2 \mathrm{H}), 3.95(\mathrm{td}, J=6.2,8.7 \mathrm{~Hz}, 2 \mathrm{H}), 4.45(\mathrm{~d}, J=6.0 \mathrm{~Hz}, 2 \mathrm{H}), 7.52$ (s, 2H). ${ }^{13} \mathrm{C}$ NMR (75 MHz; $\left.\mathrm{CDCl}_{3}\right): \delta 29.7\left(\mathrm{CH}_{2}\right), 34.6(\mathrm{CH}), 50.2$ $\left(\mathrm{CH}_{2}\right), 65.0\left(\mathrm{CH}_{2}\right), 74.9(\mathrm{CH}), 99.2(\mathrm{C}), 119.8(\mathrm{CN}), 121.4(\mathrm{C}), 135.0$ (CH), 147.1 (C). IR (neat): 2940, 2868, 2847, 2211, 1612, 1508, 1295, 1054, 733. GC/MS $m / z$ (abundancy \%): $282\left(44, \mathrm{M}^{+}\right), 237$ (100), 55 (30).

4.5.19. (3bR,6aR,9aR,12aR)-2-(trifluoromethyl)3b,5,6,6a,9a,10,11,12a-octahydro-7H,9H-furo[3,2-c]furo[2',3':4,5] pyrido[3,2,1-ij]quinoline (( \pm$)-\mathbf{1 0 T})$

Column chromatography on silica gel (dichloromethane/ethyl acetate $=3: 0.05 \mathrm{v} / \mathrm{v}$ ) afforded $68.2 \mathrm{mg}$ of the title product in $42 \%$ 
yield as a white solid. Mp: $126.8-127.6{ }^{\circ} \mathrm{C} .{ }^{1} \mathrm{H}$ NMR $(300 \mathrm{MHz}$, $\left.\mathrm{CDCl}_{3}\right): \delta 1.83-1.99(\mathrm{~m}, 2 \mathrm{H}), 2.24-2.25(\mathrm{~m}, 2 \mathrm{H}), 2.53-2.64(\mathrm{~m}, 2 \mathrm{H})$, 2.91 (dd, $J=8.1,11.7 \mathrm{~Hz}, 2 \mathrm{H}$ ), 3.08 (dd, $J=4.8,11.7 \mathrm{~Hz}, 2 \mathrm{H}$ ), 3.82 (td, $J=6.9,8.4 \mathrm{~Hz}, 2 \mathrm{H}), 3.89(\mathrm{td}, J=5.4,8.4 \mathrm{~Hz}, 2 \mathrm{H}), 4.72(\mathrm{~d}, J=6.0 \mathrm{~Hz}$, $2 \mathrm{H}), 7.50(\mathrm{~s}, 2 \mathrm{H}) .{ }^{13} \mathrm{C} \mathrm{NMR}\left(75 \mathrm{MHz}, \mathrm{CDCl}_{3}\right): \delta 29.3\left(\mathrm{CH}_{2}\right), 35.7(\mathrm{CH})$, $50.7\left(\mathrm{CH}_{2}\right), 65.7\left(\mathrm{CH}_{2}\right), 75.0(\mathrm{CH}), 119.4\left(\mathrm{q}, \mathrm{J}_{\mathrm{C}-\mathrm{F}}=32.6 \mathrm{~Hz}, \mathrm{CH}\right), 122.8$ (C), 124.6 (q, JC-F $\left.=278.9 \mathrm{~Hz}, \mathrm{CF}_{3}\right), 127.7$ (q, JC-F $\left.=3.8 \mathrm{~Hz}, \mathrm{C}\right), 145.7$ (C). IR (neat): 2947, 2864, 1622, 1510, 1322, 1103, 733. GC/MS m/z (abundancy \%): 325 (41, M $\mathrm{M}^{+}$), 280 (100), 55 (37).

\subsubsection{0. (3bR,6aR,9aS,12aS)-2-(trifluoromethyl)-}

3b,5,6,6a,9a,10,11,12a-octahydro-7H,9H-furo[3,2-c]furo[2',3':4,5] pyrido[3,2,1-ij]quinoline (10C)

Column chromatography on silica gel (hexane/dichloromethane/ethyl acetate $=3: 0.05 \mathrm{v} / \mathrm{v}$ ) afforded $65.0 \mathrm{mg}$ of the title product in $40 \%$ yield as a white solid. Mp: $104.5-105.6{ }^{\circ} \mathrm{C} .{ }^{1} \mathrm{H}$ NMR $\left(300 \mathrm{MHz}, \mathrm{CDCl}_{3}\right): \delta 1.70-1.79(\mathrm{~m}, 2 \mathrm{H}), 2.23-2.35(\mathrm{~m}, 2 \mathrm{H})$, $2.44-2.54(\mathrm{~m}, 2 \mathrm{H}), 2.68$ (dd, $J=10.8,11.7 \mathrm{~Hz}, 2 \mathrm{H}), 2.99$ (dd, $J=5.1$, $10.8 \mathrm{~Hz}, 2 \mathrm{H}), 3.83(\mathrm{td}, J=6.3,8.7 \mathrm{~Hz}, 2 \mathrm{H}), 3.97(\mathrm{td}, J=6.3,8.7 \mathrm{~Hz}$, $2 \mathrm{H}), 4.51(\mathrm{~d}, J=4.8 \mathrm{~Hz}, 2 \mathrm{H}), 7.55(\mathrm{~s}, 2 \mathrm{H}) .{ }^{13} \mathrm{C} \mathrm{NMR}\left(75 \mathrm{MHz} \mathrm{CDCl}_{3}\right)$ : $\delta 29.9\left(\mathrm{CH}_{2}\right), 34.9(\mathrm{CH}), 50.6\left(\mathrm{CH}_{2}\right), 65.0\left(\mathrm{CH}_{2}\right), 75.4(\mathrm{CH}), 119.1\left(\mathrm{q}, \mathrm{J}_{\mathrm{C}}\right.$ $\mathrm{F}=32.7 \mathrm{~Hz}, \mathrm{CH}), 122.7(\mathrm{C}), 124.6\left(\mathrm{q}, \mathrm{J}_{\mathrm{C}-\mathrm{F}}=269.2 \mathrm{~Hz}, \mathrm{CF}_{3}\right), 128.2\left(\mathrm{q}, \mathrm{J}_{\mathrm{C}}\right.$ $\mathrm{F}=3.8 \mathrm{~Hz}, \mathrm{C}$ ), 146.4 (C). IR (neat): 2968, 2856, 1620, 1514, 1322, 1059, 737. GC/MS $m / z$ (abundancy \%): $325\left(42, \mathrm{M}^{+}\right), 280$ (100), 55 (40).

4.5.21. (3bR,6aR,9aR,12aR)-2-phenyl-3b,5,6,6a,9a,10,11,12aoctahydro-7H,9H-furo[3,2-c]furo[2',3':4,5]pyrido[3,2,1-ij]quinoline (( \pm$)-11 T)$

Column chromatography on silica gel (dichloromethane/ethyl acetate $=3: 0.1 \mathrm{v} / \mathrm{v}$ ) afforded $48.2 \mathrm{mg}$ of the title product in $29 \%$ yield as a yellow solid. Mp: $113.2-113.8^{\circ} \mathrm{C} .{ }^{1} \mathrm{H}$ NMR $(300 \mathrm{MHz}$, $\left.\mathrm{CDCl}_{3}\right): \delta 1.87-1.98(\mathrm{~m}, 2 \mathrm{H}), 2.12-2.23(\mathrm{~m}, 2 \mathrm{H}), 2.56-2.66(\mathrm{~m}, 2 \mathrm{H})$, $2.86(\mathrm{dd}, J=7.6,11.4 \mathrm{~Hz}, 2 \mathrm{H}), 3.01(\mathrm{dd}, J=4.5,11.4 \mathrm{~Hz}, 2 \mathrm{H}), 3.81(\mathrm{td}$, $J=7.5,8.4 \mathrm{~Hz}, 2 \mathrm{H}) ; 3.92(\mathrm{td}, J=5.4,8.4 \mathrm{~Hz}, 2 \mathrm{H}), 4.80(\mathrm{~d}, J=6.0 \mathrm{~Hz}$, $2 \mathrm{H}), 7.22(\mathrm{t}, J=7.5 \mathrm{~Hz}, 1 \mathrm{H}), 7.35(\mathrm{t}, J=7.5 \mathrm{~Hz}, 2 \mathrm{H}), 7.54(\mathrm{~s}, 2 \mathrm{H}), 7.57$ $(\mathrm{d}, J=7.5 \mathrm{~Hz}, 2 \mathrm{H}) .{ }^{13} \mathrm{C} \mathrm{NMR}\left(75 \mathrm{MHz}, \mathrm{CDCl}_{3}\right): \delta 29.5\left(\mathrm{CH}_{2}\right), 36.2(\mathrm{CH})$, $51.3\left(\mathrm{CH}_{2}\right), 65.8\left(\mathrm{CH}_{2}\right), 75.6(\mathrm{CH}), 122.5(\mathrm{C}), 126.1(\mathrm{CH}), 126.4(\mathrm{CH})$, $128.5(\mathrm{CH}), 129.2(\mathrm{CH}), 130.9(\mathrm{C}), 140.7$ (C), 143.1 (C). IR (neat): 2930, $2869,2829,1614,1487,1453,1048,731,697 . \mathrm{GC} / \mathrm{MS} m / z$ (abundancy \%): $333\left(100, \mathrm{M}^{+}\right), 288$ (89), 55 (13).

\subsubsection{2. (3bR,6aR,9aS,12aS)-2-phenyl-3b,5,6,6a,9a,10,11,12a-} octahydro-7H,9H-furo[3,2-c]furo[2',3':4,5]pyrido[3,2,1-ij]quinoline

(11C)

Column chromatography on silica gel (dichloromethane/ethyl acetate $=3: 0.1 \mathrm{v} / \mathrm{v}$ ) afforded $54.9 \mathrm{mg}$ of the title product in $33 \%$ yield as a yellow solid. Mp: $94.7-95.6{ }^{\circ} \mathrm{C} .{ }^{1} \mathrm{H}$ NMR $(300 \mathrm{MHz}$, $\left.\mathrm{CDCl}_{3}\right): \delta 1.70-1.79(\mathrm{~m}, 2 \mathrm{H}), 2.24-2.36(\mathrm{~m}, 2 \mathrm{H}), 2.49-2.61(\mathrm{~m}, 2 \mathrm{H})$, 2.64 (dd, $J=10.5,12.0 \mathrm{~Hz}, 2 \mathrm{H}), 2.97$ (dd, $J=4.5,10.5 \mathrm{~Hz}, 2 \mathrm{H}$ ), 3.85 $(\mathrm{td}, J=6.3,8.7 \mathrm{~Hz}, 2 \mathrm{H}), 3.99(\mathrm{td}, J=6.3,8.1 \mathrm{~Hz}, 2 \mathrm{H}), 4.60(\mathrm{~d}$, $J=4.5 \mathrm{~Hz}, 2 \mathrm{H}), 7.25(\mathrm{t}, J=7.5 \mathrm{~Hz}, 1 \mathrm{H}), 7.37(\mathrm{t}, J=7.5 \mathrm{~Hz}, 2 \mathrm{H}), 7.59$ (d, $J=7.5 \mathrm{~Hz}, 1 \mathrm{H}), 7.61(\mathrm{~s}, 2 \mathrm{H}) .{ }^{13} \mathrm{C} \mathrm{NMR}\left(75 \mathrm{MHz}, \mathrm{CDCl}_{3}\right): \delta 30.1\left(\mathrm{CH}_{2}\right)$, $35.4(\mathrm{CH}), 51.1\left(\mathrm{CH}_{2}\right), 65.1\left(\mathrm{CH}_{2}\right), 75.9(\mathrm{CH}), 121.8(\mathrm{C}), 126.1(\mathrm{CH})$, $126.3(\mathrm{CH}), 128.5(\mathrm{CH}), 129.7(\mathrm{CH}), 130.7(\mathrm{C}), 140.6(\mathrm{C}), 143.5(\mathrm{C})$. IR (neat): $2926,2862,2822,1616,1485,1451,1056,772,703$. GC/MS m/ $z$ (abundancy \%): 333 (100, $\mathrm{M}^{+}$), 288 (95), 55 (13).

4.5.23. (3bR,6aR,9aR,12aR)-2-phenoxy-3b,5,6,6a,9a,10,11,12aoctahydro-7H,9Hfuro[3,2-c]furo[2',3':4,5]pyrido[3,2,1-ij]quinoline (( \pm$)-12 T)$

Column chromatography on silica gel (hexane/dichloromethane/ethyl acetate $=4: 2: 1 \mathrm{v} / \mathrm{v}$ ) afforded $59.3 \mathrm{mg}$ of the title product in $34 \%$ yield as a brown oil. ${ }^{1} \mathrm{H}$ NMR $\left(300 \mathrm{MHz}, \mathrm{CDCl}_{3}\right)$ : o $1.88-1.99(\mathrm{~m}, 2 \mathrm{H}), 2.11-2.22(\mathrm{~m}, 2 \mathrm{H}), 2.57-2.68(\mathrm{~m}, 2 \mathrm{H}), 2.82(\mathrm{dd}$,
$\mathrm{J}=7.6$ e $11.3 \mathrm{~Hz}, 2 \mathrm{H}), 2.98(\mathrm{dd}, J=4.4,11.3 \mathrm{~Hz}, 2 \mathrm{H}), 3.77(\mathrm{td}, J=7.2$, $8.4 \mathrm{~Hz}, 2 \mathrm{H}), 3.89(\mathrm{td}, J=5.4,8.4 \mathrm{~Hz}, 2 \mathrm{H}), 4.69(\mathrm{~d}, J=6.6 \mathrm{~Hz}, 2 \mathrm{H}), 7.00$ (s, 2H), 6.95-7.03 (m, 1H), 7.23-7.29 (m, 4H). ${ }^{13} \mathrm{C} \mathrm{NMR} \mathrm{(75} \mathrm{MHz;}$ $\left.\mathrm{CDCl}_{3}\right): \delta 30.2\left(\mathrm{CH}_{2}\right), 35.6(\mathrm{CH}), 51.6\left(\mathrm{CH}_{2}\right), 65.3\left(\mathrm{CH}_{2}\right), 75.8(\mathrm{CH})$, $117.8(\mathrm{CH}), 122.2(\mathrm{CH}), 122.7(\mathrm{C}), 123.1(\mathrm{CH}), 129.5(\mathrm{CH}), 140.8(\mathrm{C})$, 148.2 (C), 158.5 (C). IR (neat): 2939, 2868, 2819, 1790, 1592, 1486, 1217, 1036, 872. GC/MS $m / z$ (abundancy \%): $349\left(100, \mathrm{M}^{+}\right), 304$ (76), 55 (15).

4.5.24. (3bR,6aR,9aS,12aS)-2-phenoxy-3b,5,6,6a,9a,10,11,12aoctahydro-7H,9H-furo[3,2-c]furo[2',3':4,5]pyrido[3,2,1-ij]quinoline (12C)

Column chromatography on silica gel (hexane/dichloromethane/ethyl acetate $=4: 2: 1 \mathrm{v} / \mathrm{v}$ ) afforded $55.8 \mathrm{mg}$ of the title product in $32 \%$ yield as a brown oil. ${ }^{1} \mathrm{H}$ NMR $\left(300 \mathrm{MHz}, \mathrm{CDCl}_{3}\right)$ : $\delta 1.68-1.77(\mathrm{~m}, 2 \mathrm{H}), 2.21-2.33(\mathrm{~m}, 2 \mathrm{H}), 2.46-2.53(\mathrm{~m}, 4 \mathrm{H}), 2.87$ (dd, $J=3.0,9.0 \mathrm{~Hz}, 2 \mathrm{H}), 3.71(\mathrm{td}, J=6.1,9.0 \mathrm{~Hz}, 2 \mathrm{H}), 3.89(\mathrm{td}, J=6.1$, $8.4 \mathrm{~Hz}, 2 \mathrm{H}), 4.40(\mathrm{~d}, J=3.6 \mathrm{~Hz}, 2 \mathrm{H}), 6.91(\mathrm{~s}, 2 \mathrm{H}), 6.99(\mathrm{~m}, 1 \mathrm{H})$, 7.17-7.20 (m, 4H). ${ }^{13} \mathrm{C}$ NMR (75 MHz; $\left.\mathrm{CDCl}_{3}\right): \delta 29.7\left(\mathrm{CH}_{2}\right), 30.2$ $(\mathrm{CH}), 51.6\left(\mathrm{CH}_{2}\right), 65.3\left(\mathrm{CH}_{2}\right), 75.8(\mathrm{CH}), 117.8(\mathrm{CH}), 122.2(\mathrm{CH}), 122.7$ (C), $123.1(\mathrm{CH}), 129.5(\mathrm{CH}), 140.8(\mathrm{C}), 148.2(\mathrm{C}), 158.5$ (C). IR (neat): 2937, 2868, 2820, 2790, 1591, 1485, 1216, 1049, 875. GC/MS m/z (abundancy \%): 349 (100, $\mathrm{M}^{+}$), 304 (74), 55 (13).

\section{Acknowledgements}

The authors are grateful for the financial support provided by Fundação de Amparo à Pesquisa do Estado de Minas Gerais (FAPEMIG), Conselho Nacional de Desenvolvimento Científico e Tecnológico (CNPq), Coordenação de Aperfeiçoamento de Pessoal de Nível Superior - Brasil (CAPES - Finance Code 001) and Consejo Nacional de Investigaciones Científicas y Técnicas (CONICET, Argentina). FTM, GWA, MJS and SAF were supported by Research Fellowships from CNPq. This work was supported by the National Program for Academic Cooperation (PROCAD) of CAPES/Brazil.

\section{Appendix A. Supplementary data}

Supplementary data to this article can be found online at https://doi.org/10.1016/j.tet.2019.05.049.

\section{References}

[1] a) A.T. Bell, Science 299 (2003) 1688-1691;

b) Y. Liu, G. Zhao, D. Wang, Y. Li, Natl. Sci. Rev. 2 (2015) 150-166; c) J.H. Clark, Pure Appl. Chem. 73 (2001) 103-111.

[2] a) R. Warias, A. Zaghi, J.J. Heiland, S.K. Piendl, K. Gilmore, P.H. Seeberger, A. Massi, D. Belder, ChemCatChem 10 (2018) 5382-5385;

b) J. Tuma, M. Kohout, RSC Adv. 8 (2018) 1174-1181;

c) R. Porta, M. Benaglia, R. Annunziata, A. Puglisi, G. Celentano, Adv. Synth. Catal. 359 (2017) 2375-2382;

d) S. Cañellas, C. Ayats, A.H. Henseler, M.A. Pericas, ACS Catal. 7 (2017) 1383-1391;

e) J.V. de Assis, P.A.S. Abranches, I.B. Braga, O.M.P. Zuñiga, A.G. Sathicq, G.P. Romanelli, A.G. Sato, S.A. Fernandes, RSC Adv. 6 (2016) 24285-24289; f) Z. Zarnegar, J. Safar, New J. Chem. 40 (2016) 7986-7995;

g) S.H. Newland, D.J. Xuereb, E. Gianotti, L. Marchese, R. Riosa, R. Raja, Catal. Sci. Technol. 5 (2015) 660-665;

h) G.S. Scatena, A.F. de la Torre, Q.B. Cass, D.G. Rivera, M.W. Paixão, ChemCatChem 6 (2014) 3208-3214.

[3] J.H. Lee, S.H. Jung, S.S. Lee, K.-Y. Kwon, K. Sakurai, J. Jaworski, J.H. Jung, ACS Nano 11 (2017) 4155-4164.

[4] a) P.A.S. Abranches, E.V.V. Varejão, C.M. da Silva, A. de Fátima, T.F.F. Magalhães, D.L. da Silva, M.A. de Resende-Stoianoff, S. Reis, C.S. Nascimento Jr., W.B. de Almeida, I.M. Figueiredo, S.A. Fernandes, RSC Adv. 5 (2015) 44317;

b) E.V.V. Varejã́o, Â. de Fátima, S.A. Fernandes, Curr. Pharmaceut. Des. 19 (2013) 6507-6521;

c) L.M. Arantes, E.V.V. Varejão, K.J. Pelizzaro-Rocha, C.M.S. Cereda, E. de Paula, M.P. Lourenço, H.A. Duarte, S.A. Fernandes, Chem. Biol. Drug Des. 83 (2014) 550-559; 
d) J.V. de Assis, M.G. Teixeira, C.G.P. Soares, J.F. Lopes, G.S.L. Carvalho, M.C.S. Lourenço, M.V. de Almeida, W.B. de Almeida, S.A. Fernandes, Eur. J. Pharm. Sci. 47 (2012) 539-548.

[5] a) X. Yao, X. Wang, T. Jiang, X. Ma, H. Tian, Langmuir 31 (2015) 13647-13654; b) A. Díaz-Moscoso, F.A. Arroyave, P. Ballester, Chem. Commun. 52 (2016) 3046-3049.

[6] a) J. Matthias, R. Yuliya, M. Olena, M. Thorsten, M. Ingo, D. Gregor, E.M. Piotr, G. Juergen, B. Volker, J. Andreas, Nat. Nanotechnol. 4 (2009) 225;

b) M. Zhang, X. Yan, F. Huang, Z. Niu, H.W. Gibson, Acc. Chem. Res. 47 (2014) 1995.

[7] C. Schöttle, E.L. Clark, A. Harker, A. Solovyov, A.T. Bell, A. Katz, Chem. Commun. 53 (2017) 10870-10873.

[8] a) T.R.M. Rezende, J.O.S. Varejão, A.L.L.A. Sousa, S.M.B. Castañeda, S.A. Fernandes, Org. Biomol. Chem. 17 (2019) 2913-2922;

b) N.A. Liberto, J.B. Simões, S.P. Silva, C.J. da Silva, L.V. Modolo, A. de Fátima, L.M. Silva, M. Derita, S. Zacchino, O.M.P. Zuñiga, G.P. Romanelli, S.A. Fernandes, Bioorg. Med. Chem. 25 (2017) 1153-1162;

c) V. Palermo, A. Sathicq, N. Liberto, S. Fernandes, P. Langer, J. Jios, G. Romanelli, Tetrahedron Lett. 57 (2016) 2049-2054. J. B. Simões, D. L. da Silva, A. de Fátima, S. A. Fernandes, Curr. Org. Chem. 16 (2012) 949-971; d) D.L. da Silva, B.S. Terra, M.R. Lage, A.L.T.G. Ruiz, C.C. da Silva, J.E. de Carvalho, J.W.M. Carneiro, F.T. Martins, S.A. Fernades, A. de Fátima, Org. Biomol. Chem. 13 (2015) 3280-3287;

e) R. Natalino, E.V.V. Varejão, M.J. da Silva, A.L. Cardoso, S.A. Fernandes, Catal. Sci. Technol. 4 (2014) 1369-1375;

f) S.A. Fernandes, R. Natalino, M.J. da Silva, C.F. Lima, Catal. Commun. 26 (2012) 127-131;

g) S.A. Fernandes, R. Natalino, P.A.R. Gazolla, M.J. da Silva, G.N. Jham, Tetrahedron Lett. 53 (2012) 1630-1633;

h) D.M. Homden, C. Redshaw, Chem. Rev. 108 (2008) 5086-5130.

[9] a) J.-F. Huang, J.-M. Liu, L.-M. Xiao, Y.-H. Zhong, L. Liu, S. Qin, J. Guo, C.-Y. Su, J. Mater. Chem. A 7 (2019) 2993-2999;

b) S. Wang, Y. Bi, X. Hang, X. Zhu, W. Liao, Z. Anorg. Allg. Chem. 643 (2017) 160-165;

c) S. Wang, X. Hang, X. Zhu, H. Han, G. Zhang, W. Liao, Polyhedron 130 (2017) 75-80;

d) M.M. Nigra, J.-M. Ha, A. Katz, Catal. Sci. Technol. 3 (2013) 2976-2983;

e) J.M. Notestein, E. Iglesia, A. Katz, J. Am. Chem. Soc. 126 (2004) 16478-16486;

f) S. Meninno, A. Parrella, G. Brancatelli, S. Geremia, C. Gaeta, C. Talotta, P. Neri, A. Lattanzi, Org. Lett. 17 (2015) 5100-5103:

g) J.D. Bass, A. Solovyov, A.J. Pascall, A. Katz, J. Am. Chem. Soc. 128 (2006) 3737-3747;

h) A. Mouradzadegun, A.R. Kiasat, P.K. Fard, Catal. Commun. 29 (2012) 1-5.

[10] a) D. Maity, A.K. Manna, D. Karthigeyan, T.K. Kundu, S.K. Pati, T. Govindaraju, Chem. Eur. J. 17 (2011) 11152-11161;

b) Y.W. Choi, J.J. Lee, G.R. You, S.Y. Lee, C. Kim, RSC Adv. 5 (2015) 86463-86472;

c) D. Singhal, N. Gupta, A.K. Singh, New J. Chem. 40 (2016) 7536-7541.

[11] G. Wu, F. Kong, J. Li, W. Chen, C. Zhang, Q. Chen, X. Zhang, S. Dai, J. Synth. Meth. 180 (2013) 9-15.

[12] a) Y. Zhang, D. Luo, L. Yang, W. Cheng, L. He, G. Kuang, M. Li, Y. Li, G. Wang, J. Natl. Prod. 81 (2018) 2259-2265;

b) Y. Zhang, L. Yang, D. Luo, N. Chen, Z. Wu, W. Ye, Y. Li, G. Wang, Org. Lett. 20 (2018) 5942-5946.

[13] Z. Vejdelek, M. Protiva, Collect. Czechoslov. Chem. Commun. 55 (1990) 1290-1296.

[14] C. S. Sinha, S. S. Bhat, K. Chow, R. L. Beard, J. E. Donello, US 2009/0231322 A1 2009.

[15] a) M.W. Beck, R.S. Kathayat, C.M. Cham, E.B. Changb, B.C. Dickinson, Chem. Sci. 8 (2017) 7588-7592;

b) A. Schulz-Fincke, A.S. Tikhomirov, A. Braune, T. Girbl, E. Gilberg, J. Bajorath, M. Blaut, S. Nourshargh, M. Gütschow, Biochemistry 57 (2018) 742-752; c) T.F. Brewer, G. Burgos-Barragan, N. Wit, K.J. Patelbc, C.J. Chang, Chem. Sci. 8 (2017) 4073-4081.

[16] F. Liu, H. Xu, H. Zhang, L. Chen, J. Liu, S. Bo, Z. Zhen, X. Liu, L. Qiu, Dyes Pigments 134 (2016) 358-367.

[17] D.B. Glass, A. Weissberger, Org. Synth. 26 (1946) 40.

[18] a) E. Zysman-Colman, J.S. Siegel, Can. J. Chem. 87 (2009) 440-447; b) D.P. Specht, P.A. Martic, S. Farid, Tetrahedron 38 (1982) 1203-1211.
[19] J. Zhu, H. Bienaymé (Eds.), Multicomponent Reactions, Wiley-VCH, Weinheim, Germany, 2005, p. 76.

[20] a) L. Levi, T.J.J. Müller, Chem. Soc. Rev. 45 (2016) 2825-2846; b) S. Maity, A. Kundu, A. Pramanik, RSC Adv. 5 (2015) 52852-52865; c) F. Vitório, T.M. Pereira, R.N. Castro, G.P. Guedes, C.S. Graebin, A.E. Kümmerle, New J. Chem. 39 (2015) 2323-2332.

[21] a) C.A.M. Bonilla, C.E.P. Galvis, L.Y.V. Méndez, V.V. Kouznetsov, RSC Adv. 6 (2016) 37478-37486;

b) W. Dai, X.-L. Jiang, J.-Y. Tao, F. Shi, J. Org. Chem. 81 (2016) 185-192;

c) L.-P. Li, X. Cai, Y. Xiang, Y. Zhang, J. Song, D.-C. Yang, Z. Guan, Y.-H. He, Green Chem. 17 (2015) 3148-3156;

d) I. Muthukrishnan, V. Sridharan, J.C. Menéndez, Chem. Rev. 119 (8) (2019) 5057-5191.

[22] a) N.A. Liberto, J.B. Simões, S.P. Silva, C.J. da Silva, L.V. Modolo, A. de Fátima, L.M. Silva, M. Derita, S. Zacchino, O.M.P. Zuninga, G.P. Romanelli, S.A. Fernandes Bioorg. Med. Chem. 25 (2017) 1153-1162;

b) J. Cai, F. Li, G.-J. Deng, X. Ji, H. Huang, Green Chem. 18 (2016) 3503-3506; c) H.-X. Luo, Y. Niu, X. Jin, X.-P. Cao, X. Yao, X.-S. Ye, Org. Biomol. Chem. 14 (2016) 4185-4188;

d) C.R. Borel, L.C.A. Barbosa, C.R.A. Maltha, S.A. Fernandes, Tetrahedron Lett. 56 (2015) 662-665;

e) J.B. Simoés, A. de Fátima, A.A. Sabino, L.C.A. Barbosa, S.A. Fernandes, RSC Adv. 4 (2014) 18612-18615.

[23] a) P.A.S. Abranches, W.F. de Paiva, Â. de Fátima, F.T. Martins, S. A Fernandes, J. Org. Chem. 83 (2018) 1761-1771;

b) J.B. Simões, A. de Fátima, A.A. Sabino, F.J.T. de Aquino, D.L. da Silva L.C.A. Barbosa, S.A. Fernandes, Org. Biomol. Chem. 11 (2013) 5069-5073;

c) S. Kobayashi, H. Miyamura, H. JP JP 5293651 B2 2013.9.18 2013; d) C. Wang, Z.-Y. Han, H.-W. Luo, L.-Z. Gong, Org. Lett. 12 (2010) 2266-2269; e) J. Legros, B. Crousse, M. Ourévitch, D. Bonnet-Delpon, Synlett 12 (2006) 1899-1902;

f) J.M. Mellor, G.D. Merriman, Tetrahedron 51 (1995) 6115-6132;

j) M. Minakawa, K. Watanabe, S. Toyoda, Y. Uozumi, A.-E., Synlett 29 (2018); 1) A. Labed, F. Jiang, I. Labed, A. Lator, M. Peters, M. Achard, A. Kabouche, Z. Kabouche, G.M. Sharma, C. Bruneau, ChemCatChem 7 (2015) 1090-1096.m) J. O. S. Varejão, E. V. V. Varejão, S. A. Fernandes, doi:10.1002/ ejoc. 201900398.

[24] J.J. Martínez, E. Nope, H. Rojas, M.H. Brijaldo, F. Passos, G. Romanelli, J. Mol. Catal. A Chem. 392 (2014) 235-240.

[25] S.G. Casuscelli, M.E. Crivello, C.F. Perez, G. Ghione, E.R. Herrero, L.R. Pizzio, P.G. Vázquez, C.V. Cáceres, M.N. Blanco, Appl. Catal. A Gen. 274 (2004) $115-122$.

[26] G. Boven, M.L.C.M. Oosterling, G. Challa, A.J. Schonten, Polymer 31 (1990) 2377-2383.

[27] a) V.L. Furer, E.I. Borisoglebskaya, V.I. Kovalenko, Spectrochim. Acta, Part A 61 (2005) 355-359;

b) S. Shinkai, K. Araki, T. Tsubaki, T. Arimura, O. Manabe, J. Chem. Soc. Perkin Trans. I (1987) 2297-2299.

[28] S.M. Alahmadi, S. Mohamad, M.J. Maah, Int. J. Mol. Sci. 13 (2012) $13726-13736$.

[29] R. Brindle, K. Albert, S.J. Harris, C. Triiltzsch, E. Horned, J.D. Glennon, J. Chromatogr. A 73 (1996) 41-46.

[30] X.-Z. Xiao, Y.-Q. Feng, S.-L. Da, Y. Zhang, Chromatographia 49 (1999) 643-648.

[31] A. Katz, P. Costa, A.C.P. Lam, J.M. Notestein, Chem. Mater. 14 (2002) $3364-3368$

[32] M. Kruk, M. Jaroniec, Chem. Mater. 13 (2001) 3169-3183.

[33] J.C. Groen, L.A.A. Peffer, J. Pérez-Ramírez, Microporous Mesoporous Mater. 60 (2003) 1-17.

[34] S.M. Alahmadi, S. Mohamad, M.J. Maah, Int. J. Mol. Sci. 13 (2012) $13726-13736$.

[35] A. Katz, P. da Costa, A.C.P. Lam, J.M. Notestein, Chem. Mater. 14 (2002) 3364-3368.

[36] a) H. Liu, G. Dagousset, G. Masson, P. Retailleau, J. Zhu, J. Am. Chem. Soc. 131 (2009) 4598-4599;

b) G. Dagousset, J. Zhu, G. Masson, J. Am. Chem. Soc. 133 (2011) 14804-14813.

[37] M.C. Burla, R. Caliandro, M. Camalli, B. Carrozzini, G.L. Cascarano, L. De Caro, C. Giacovazzo, G. Polidori, R. Spagna, J. Appl. Crystallogr. 38 (2005) 381-388.

[38] G.M. Sheldrick, Acta Crystallogr. Sect. C 71 (2015) 3-8.

[39] L.J. Farrugia, J. Appl. Crystallogr. 30 (1997) 565. 